\title{
Upper Cenozoic sequences in the southeastern North Sea Basin
}

\author{
JAN C. SØRENSEN \& OLAF MICHELSEN
}

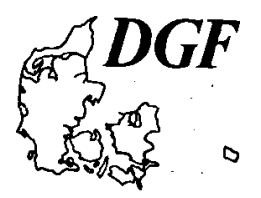

Sørensen, J. C. \& Michelsen, O.: Upper Cenozoic sequences in the southeastern North
Sea Basin. Bulletin of the Geological Society of Denmark, Vol. 42, pp. 74-95. Copenhagen. 1995-10-31. https://doi.org/10.37570/bgsd-1995-42-08

The Upper Cenozoic deposits, which cover the "mid-Miocene unconformity" in the southeastern North Sea Basin are subdivided into thirty-one sequences. Progradation from the east to the west is observed. The lowstand systems tracts appear seismically as prograding wedges. The top lowstand surface is recognized as a toplap surface in areas where high-angle progradation dominates the stratal pattern, indicating the presence of a bypass zone formed during lowstand progradation. The maximum flooding surface is identified on logs as a maximum gamma ray peak, which separates an upward fining from an upward coarsening trend. The two trends represent the transgressive and the highstand systems tracts, respectively.

Sequence boundaries are commonly associated with widespread erosion. The presence of both fluvial and submarine erosion is interpreted on the basis of the orientation of incision and the position of erosion relative to the depositional shoreline break of the preceding sequence.

In Late Miocene times the Ringkøbing-Fyn High partly separated the southeastern North Sea into two embayments, which were connected by a deep seaway towards the west. Sediment accumulation rates seem to have culminated during periods with decreasing palaeo-temperatures. During relatively cold periods, the sequences were deposited as prograding wedges with a limited lateral extent. Two periods with maximum palaeotemperatures are time-equivalent with the two most distinct maximum flooding surfaces and intervals characterized by low sediment accumulation rates.

Jan C. Sørensen \& Olaf Michelsen. Department of Earth Sciences, Aarhus University. DK-8000 Ärhus, Denmark. 30th January 1995.

\section{Introduction}

The purpose of the present study is to unravel the regional depositional pattern of the Upper Cenozoic sediments in the southeastern North Sea. The paper includes results presented in the unpublished M. Sc. thesis by Sørensen (1993).

The investigated deposits constitute the major sequence stratigraphic unit 7 described by Michelsen et al. (in press). The lower boundary of unit 7 corresponds to the so-called "mid-Miocene unconformity" which is a distinct seismic marker in the North Sea area (Deegan \& Scull, 1977), and is recognized by one or two distinct and high gamma ray peaks on petrophysical logs (Kristoffersen \& Bang, 1982). The lower boundary of unit 7 is here placed at the base of the lower gamma ray peak according to Michelsen et al. (in press). The deposits above the "mid-Miocene unconformity" are here referred to as Upper Cenozoic deposits.

According to Cameron et al. (1993), Kay (1993) has identified 26 seismic sequence boundaries within the mid Miocene to Middle Pleistocene sediments of the southern North Sea. Fourteen of these sequence boundaries were illustrated by a high resolution seismic profile (Cameron et al., 1993). Sørensen (1993) identified 16 sequence boundaries in the northern Danish North Sea sector.

The studied data comprise a grid of $14500 \mathrm{~km}$ of conventional seismic sections (SP 82, GR 86, SNSTI $83 / 87$, CGT 81 and RTD 81 surveys) covering the study area, and logs from fourteen wells (Fig. 1). The upper part of the seismic sections $(0-400 \mathrm{msec}$. twt $)$ has not been interpreted due to poor data quality.

The procedure of interpretation decribed by Vail (1987) and Van Wagoner et al. (1990) is used, integrating seismic information and log data. Isopach maps including seismic features are compiled for the sequences. Biostratigraphic data from Michelsen et al. (in press) are integrated into the analysis to establish a chronostratigraphic control. 
Fig. 1. Mesozoic structures of the North Sea Basin modified from Ziegler (1982). Insetmap of the study area with location of the seismic sections cross sections and the wells used in this paper. Sector boundaries are shown with a hatched line.
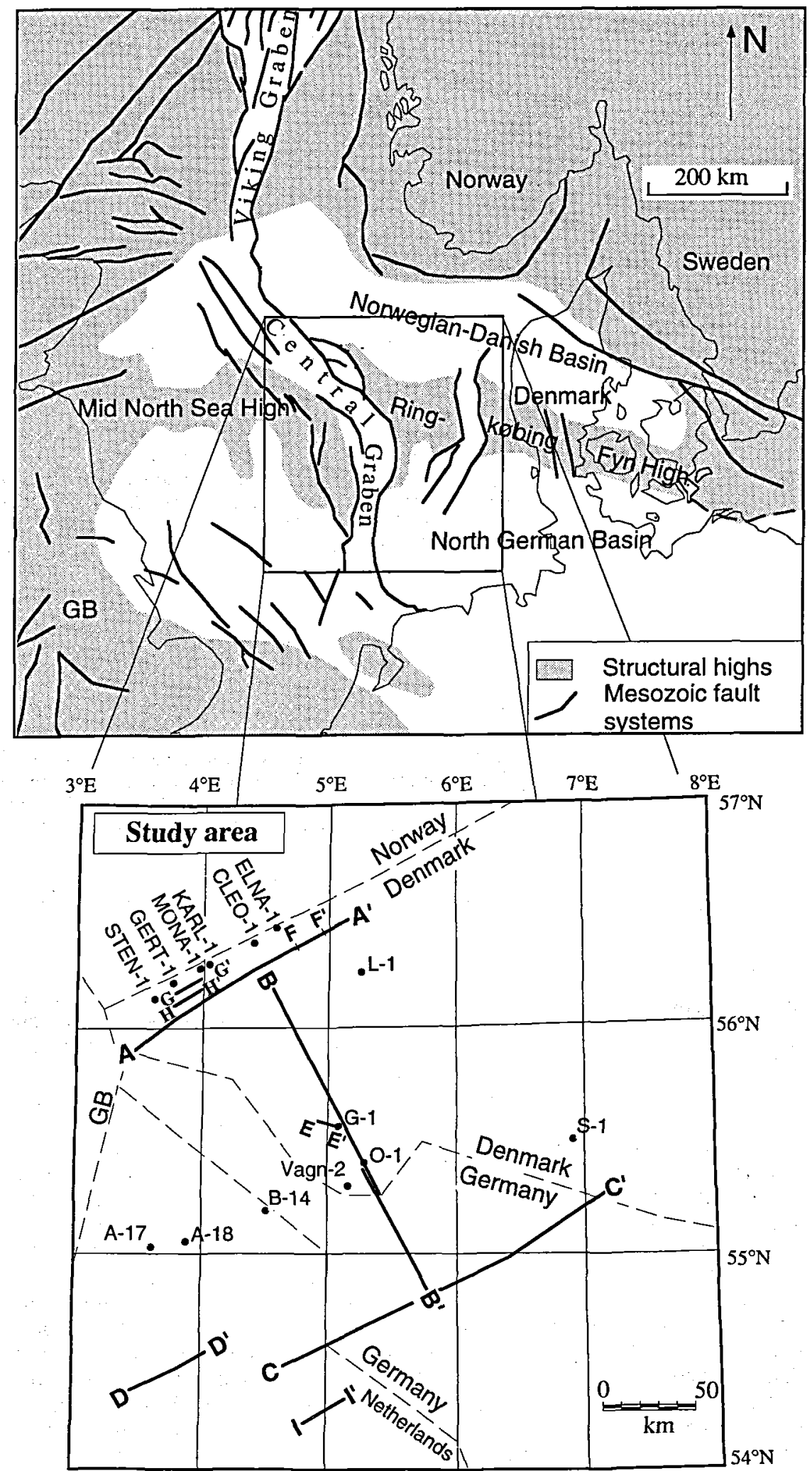


\section{Geological setting}

During most of Cenozoic times, the North Sea region appeared as an epicontinental basin, confined by landmasses except toward the north, where a narrow seaway connected it with the Norwegian-Greenland Sea (Rundberg, 1989; Ziegler, 1988). The maximum thickness of Cenozoic sediments exceeds $3000 \mathrm{~m}$ along the axes of the Mesozoic graben systems, the Central Graben and the Viking Graben (Fig. 1). The Ringkøbing-Fyn High and the Mid North Sea High have been important structural highs since Permian times, and during Cenozoic times the Ringkøbing-Fyn High acted as a submarine barrier, which influenced the depositional pattern.

The maximum thickness of the investigated Upper Cenozoic sediment package is nearly $1500 \mathrm{~m}$ in the Norwegian part of the Central Graben. The oldest part of these sediments was deposited during an increase in water depth possibly caused by rapid tectonic subsidence (Kockel, 1988).

A regional uplift of the Scandinavian region has been suggested (e. g. Jensen \& Michelsen, 1991; Jensen \& Schmidt, 1992; Japsen, 1993; Michelsen \& Nielsen, 1993). The hinge-line between the eastern uplift area and the subsidence area of the Central Graben conforms to the eastern margin of the graben (Jensen \& Michelsen, 1991). The uplift mainly occurred during the Neogene, and is estimated to $1500 \mathrm{~m}$ near the coasts of Sweden and Norway (Jensen \& Schmidt, 1992). Subsequent erosion of the uplifted areas caused accumulation of large amounts of sediments in the Central Graben area. Middle Miocene and Pliocene sedimentation in the southern North Sea was dominated by major delta systems prograding from east (Cameron et al., 1993). Bijlsma (1981) suggested that one river system, named the Baltic River System, was the transport agent of the Miocene, Pliocene and Pleistocene sediments in the North Sea Basin. The Baltic River System was destroyed by the inland-ice of the Menapian glacial (Bijlsma, 1981).

\section{Description of seismic reflection patterns}

The "mid-Miocene unconformity" is recognized as a strong seismic reflection in the central North Sea. The unconformity separates a subparallel seismic facies strongly disturbed by a great number of small scale faults, from a more continuous unfaulted reflection pattern above the unconformity (Clausen \& Korstgård, 1993). The "mid-Miocene unconformity" is conspicuous throughout the study area.

The seismic expression of the Upper Cenozoic deposits in the southern part of the study area differs from that of the northern part. The thickness of the Upper Cenozoic sediment package decreases considerably above the Ringkøbing-Fyn High. Seismic baselap fea- tures onto the flanks of the Ringkøbing-Fyn High are observed at some sequence boundaries (Fig. 2). It is therefore convenient to subdivide the study area into two embayments. The northern embayment comprises the Norwegian-Danish Basin and the northern part of the Central Graben area and the southern embayment the North German Basin and the southern part of the Central Graben area. The eastern parts of the two embayments are separated by the Ringkøbing-Fyn High. The influence of the structural high diminishes toward the west, where the two embayments are connected.

Thirty-one sequences are identified from the seismic sections. Sequence boundaries are mostly represented by strong and continuous seismic reflections. Some of the sequence boundaries are traceable throughout the study area. Other sequence boundaries are limited to either the northern or the southern embayment; e.g. the boundaries of sequences 11 to 15 merge toward the north into the upper boundary of sequence 10 (Fig. 2).

\section{Northern embayment}

Seventeen of the thirty-one sequences are identified in the northern embayment. Sequence 1 is relatively thin and has a large lateral extension. Younger sequences downlap to the west upon sequence 1. The Upper Cenozoic deposits are truncated toward the east by younger strata, probably of Quaternary age (Fig. 3).

Low-angled progradation dominates the Miocene sequences 1-16 in the northern embayment, and an overall high-angled prograding stratal geometry characterizes the Pliocene sequences 19-25 (Fig. 3). A distinct downlap surface, the maximum flooding surface, within sequence 19 marks the change from lowangled to high-angled progradation. The dominating direction of sediment transport, determined from maximal inclinations of downlapping seismic reflections, is from the northeast towards the southwest.

\section{Southern embayment}

All identified sequences, except sequences 23 and 24, are present in the southern embayment. An increasing inclination of strata is observed upward through the Upper Cenozoic succession (Fig. 4). The dominating direction of sediment transport was towards southsouthwest (sequences 1-3) and southwest (sequences 4-31). The sequences 1-15 show low-angled downlaps onto the southern flank of the Ringkøbing-Fyn High (Fig. 2). In the southwestern part of the study area, sequences 20-31 downlap directly onto the "midMiocene unconformity" (Fig. 5).

Sequences 1-3 are dominated by a low-angled stratal pattern. An upward increasing high-angled reflection pattern characterizes the successions of sequences 4 22 and $25-31$. The boundaries of sequences 7-22 and 


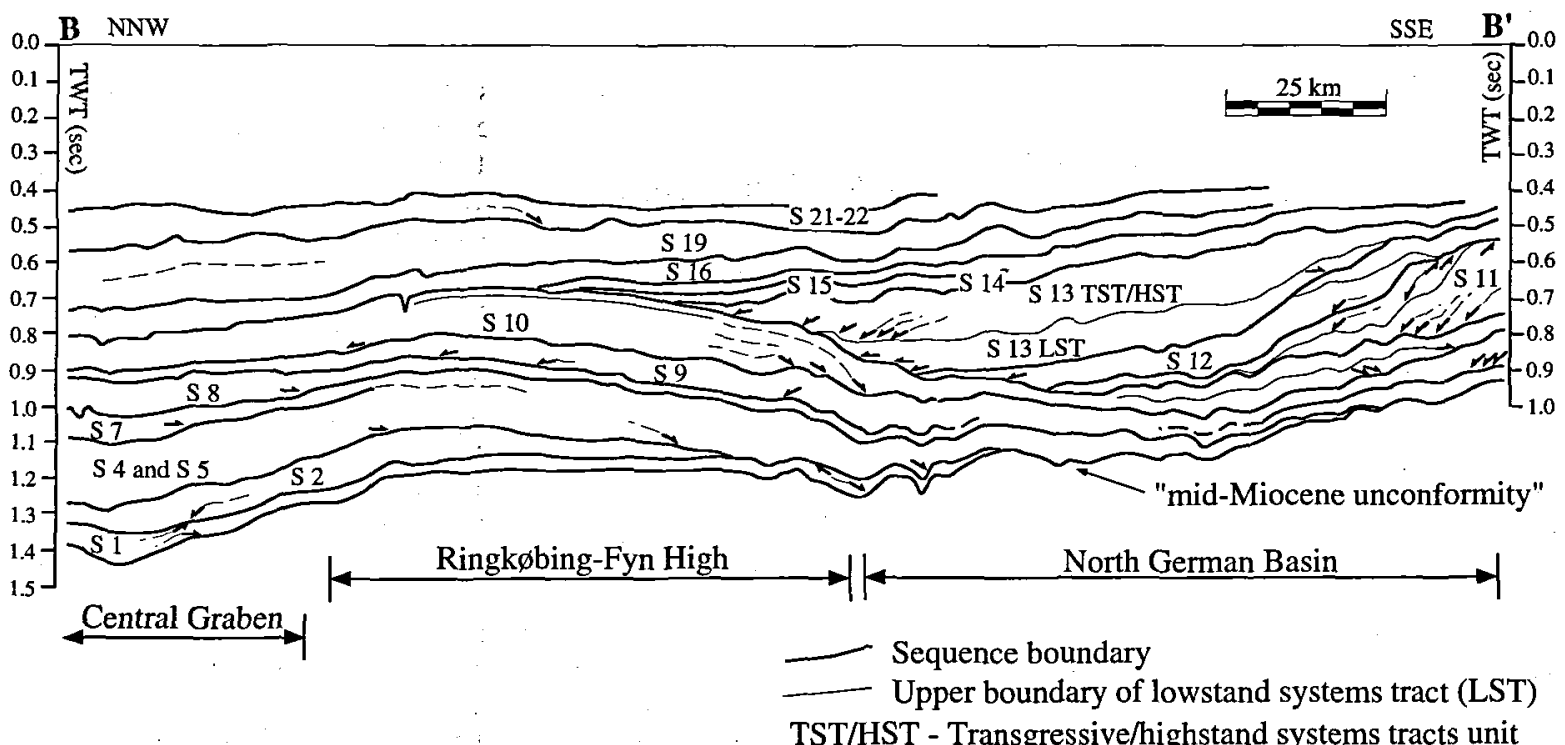

LST - Lowstand systems tract

S 19 Sequence 19

Fig. 2. Cross section B-B' (based on seismic sections). It intersects Upper Cenozoic deposits perpendicular to the dominant transport direction. Note lateral changes in location of the depocentres in the Central Graben and the North German Basin, respectively. For location see Figure 1.

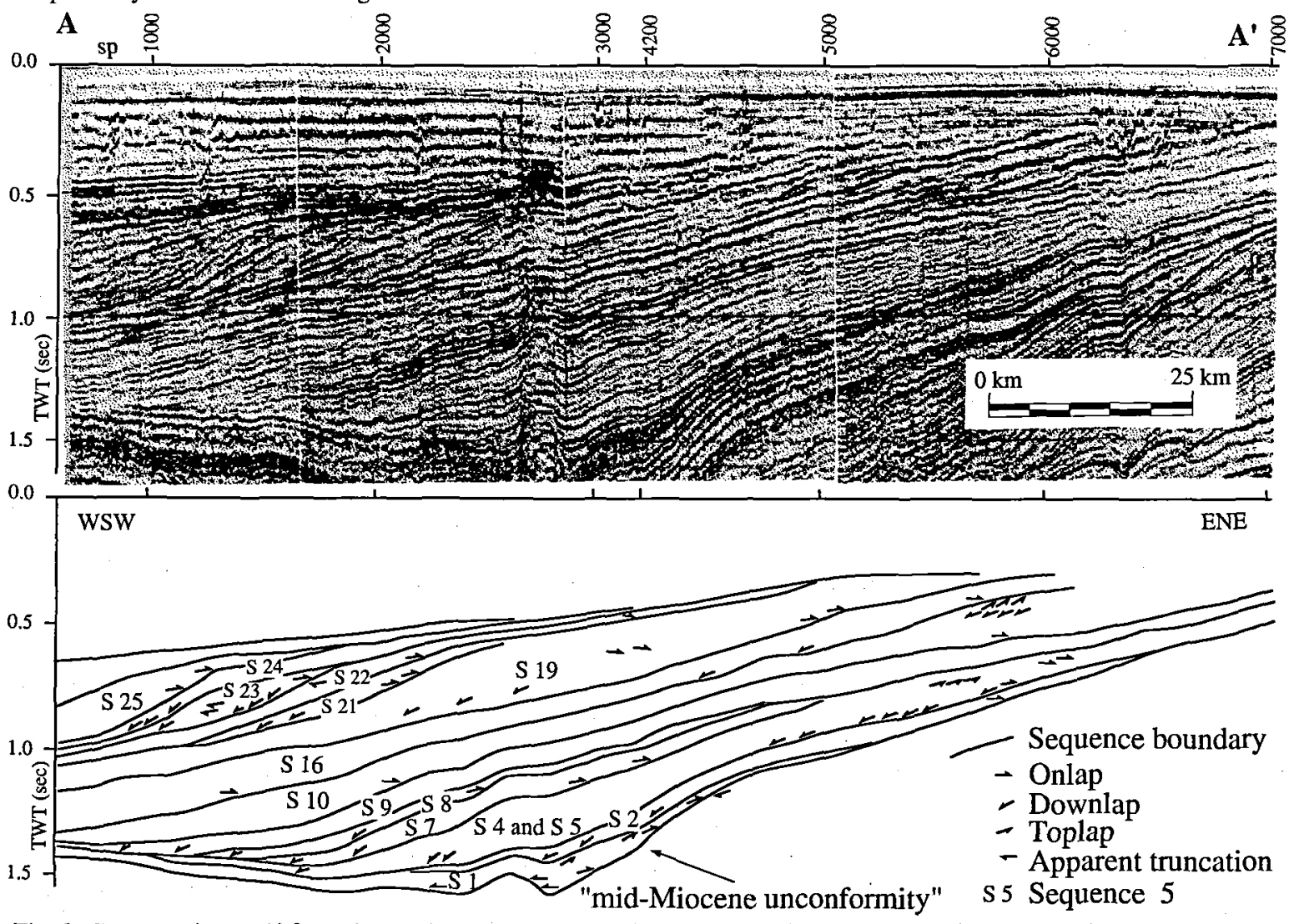

Fig. 3. Cross section A-A' from the northern part of the study area oriented parallel to the dominating direction of sediment transport. Upper part: seismic section (RTD81-22). Lower part: sequence stratigraphic interpretation of the seismic section. Low-angled progradation dominates sequence 1 to 16 . Inclination of strata increases abruptly above the maximum flooding surface of sequence 19. The sequence boundary indicated above the upper boundary of sequence 25 may correspond to the upper boundary of sequence 29. For location see Figure 1. 


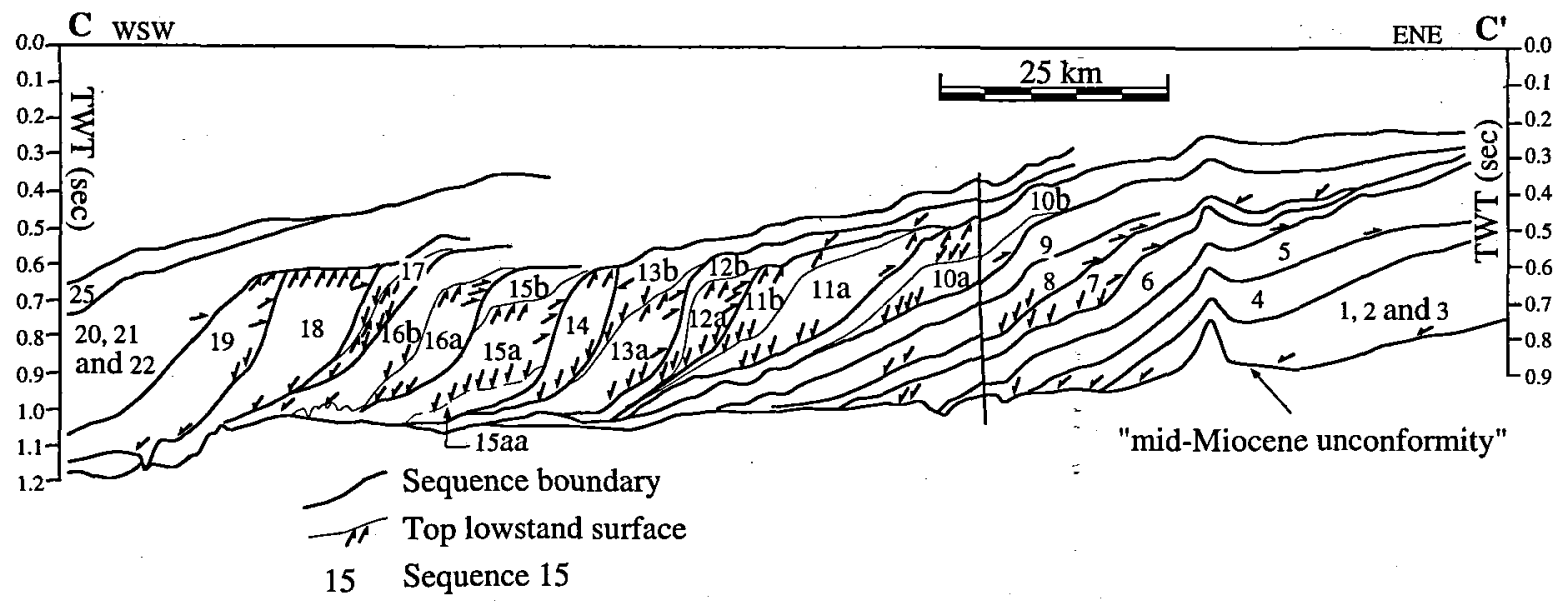

15aa and 15a Lower unit (lowstand systems tract) of sequence 15

15b Upper unit (transgressive and highstand systems tracts) of sequence 15

Fig. 4. Cross section C-C' (based on seismic sections) intersects the Upper Cenozoic deposits in the North German Basin parallel to the dominating direction of sediment transport. Inclination of the seismic reflections increases from east towards west. Sequences 11-15 are restricted to the North German Basin. For location see Figure 1.

25-31 are identified by numerous onlaps, downlaps and toplaps (Figs 4 and 5). A distinct toplap surface is distinguished within each of the sequences $10-13$ and 15-17 (Fig. 4). These sequences include prograding wedges covered by relatively thick aggrading to prograding units. The sequences thin significantly toward the west where they appear as a succession of prograding wedges covered by thin aggrading to prograding intervals (sequences 25-31) (Fig. 5).

The lower boundary of the prograding wedges is charaterized by onlaps against the underlying deposits in the updip direction and by downlaps in the downdip direction. This boundary is interpreted as the lower boundary of the lowstand deposits, i. e. the sequence boundary. The upper boundary of the prograding wedge is characterized by toplaps and by downlaps from the overlying aggrading to prograding unit. It is interpreted as the top lowstand surface (Vail et al. 1991; HellandHansen \& Gjelberg, 1994).

Mounded structures are identified by bi-directional downlaps (Fig. 6). They are located below depositional shoreline break, at the lower boundaries of sequences 15, 18 and 19 (Fig. 4). The term depositional shoreline break (Posamentier \& Vail, 1988) as used here refers to the physiographic break (apparent shelf edge) located on the upper slope of the preceding sequence.

\section{Erosional features}

Widespread erosional features can be observed at several of the sequence boundaries in the study area. Two types of erosional features are distinguished based on the orientation of the features compared to the dip direction and the position relative to the depositional shoreline break of the preceding sequence.
In the Central Graben area erosion is identified as deeply incised valleys or complex systems of smaller valleys on the seismic sections (Fig. 6). The valleys are orientated perpendicular to the dip direction (i. e. parallel to the axis of the Central Graben) and appear topographically below the depositional shoreline break of the underlying prograding deposits. Incised valleys with this orientation are most prominent at the upper boundaries of sequences $4,5,7,9,10$ and 18 . Some of the incised valleys are nearly $100 \mathrm{~m}$ deep. The walls of the incised valleys truncate underlying reflections and the fill shows onlapping reflections. Only deeply incised valleys are correlatable between different seismic sections. The area influenced by erosion shifts successively westward and the depth of incision increases up through the Upper Cenozoic succession in the Central Graben area. Submarine erosion may explain the presence of these incised valleys. Submarine erosion could have been caused by bottom currents (contourites) running along the axis of the Central Graben. Coastal parallel wind- and tide-driven currents similar to those of the Recent North Sea as described by Eisma \& Kalf (1987) may have occurred also in Late Miocene and caused the erosional troughs.

Incised valleys at the "mid-Miocene unconformity" and at the boundaries between sequences 1,2 and 3 are observed along the southern flank of the Ringk $\emptyset$ bing-Fyn High. These incised valleys are oriented parallel to the dip direction (parallel to the dominant direction of sediment transport), and located updip of the depositional shoreline break. They may therefore have been caused by fluvial incision. 


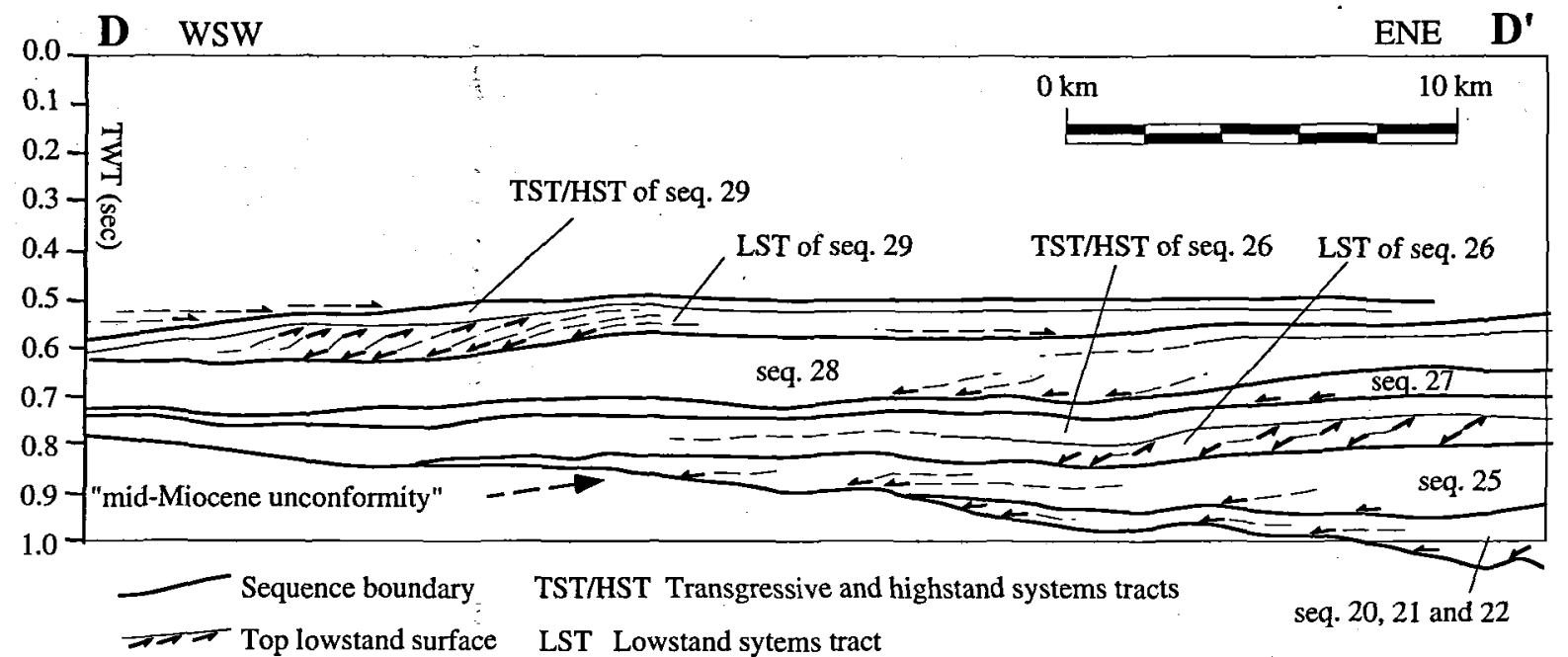

Fig. 5. Section D-D' oriented parallel to the dominating direction of sediment transport based on seismic sections from westernmost part of the study area. Note, that the Pliocene and Quaternary sequences downlap directly onto the "midMiocene unconformity". For location see Figure 1.

\section{Sequence and systems tract interpretation}

\section{Sequences}

The above-described lower boundary of the lowstand deposits can often be correlated updip to an erosional unconformity, interpreted as the sequence boundary.

Correlation of the seismic sequence boundaries to well logs shows that they are located at an abrupt shift in log readings (Figs 7 and 8), indicating changes from fine grained sediments below the boundary to more coarse-grained above. Changes in lithology across sequence boundaries are most distinct in the highangled prograding sequences represented in the A-17, A-18 and Vagn-2 wells and in the upper sections of the O-1 and S-1 wells (Fig. 7). Corresponding shifts in $\log$ readings are seen in the uppermost section of wells from the northern embayment (Fig. 8).

The gamma ray logs representing the southern embayment indicate considerable lateral lithological variations within the sequences (Fig. 7). The vertical variation in gamma ray values within each sequence is most prominent in the well logs from the Dutch sector, indicating larger grain-size variations to the west during deposition of the younger sequences. The deposits become more coarse-grained upward through the Upper Cenozoic succession (Figs 7 and 8).

Isopach maps of sequences 1-28 are presented in Figures 9-32. In some cases are two or more sequences grouped together in one isopach map (Figs 10, 11 and 26). The boundaries between sequences 4 and 5 and between sequences 20,21 and 22 appear as distinct seismic boundaries in the southern embayment, but are less distinct in the northern embayment. Sequences 4 and 5 and sequences 20,21 and 22 are consequently illustrated in two maps (Figs 11 and 26). These sequ- ences are, however, recognizable on the logs throughout the study area. The sequences appear as elongated sedimentary bodies oriented perpendicular to the dominant sediment transport direction (Figs 9-32).

The above-mentioned erosional features at the sequence boundaries are illustrated on the maps. Incised valleys oriented perpendicular to the dip direction at the upper boundaries of sequences $4,5,7,9,10$ and 18 are illustrated in Figures 4, 11, 13, 15, and 16. Incised valleys oriented parallel to the dip direction at the "mid-Miocene unconformity" and the upper boundaries of sequences 1, 2 and 3 are illustrated in Figure 10.

\section{Lowstand systems tracts}

A sequence is subdivided into a lower and an upper seismic unit, separated by the before-mentioned top lowstand surface. The lower seismic unit is always situated basinward and topographically below the depositional shoreline break of the preceding sequence, and is consequently interpreted as the lowstand systems tract (Vail, 1987; Van Wagoner et al., 1987; Posamentier et al., 1992). In sequences 19 and 26, the lowstand deposits are represented by two or three intervals with decreasing log values (wells B14 and A18), which are interpreted as stacked prograding parasequence sets (Fig. 7).

The top lowstand surface is interpreted to have been formed during lowstand progradation (Posamentier et al., 1992). Some of the top lowstand surfaces appear as truncation surfaces rather than toplap surfaces, as the underlying prograding lowstand deposits lack a sigmoidal signature. The top lowstand surface may in such cases be interpreted as an erosional surface, pro- 
G WSW

ENE $\quad \mathbf{G}^{\prime}$

$1.0 \mathrm{~g}$

O 0

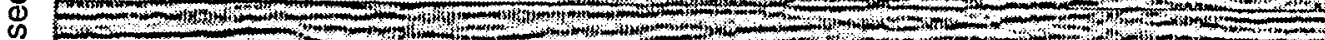

$5-10$

$3=-1,-1,-3$

1.4 -

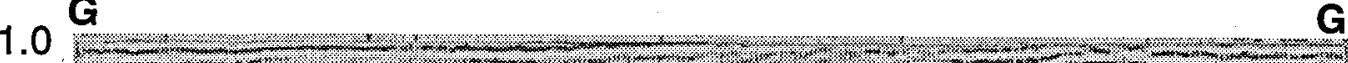

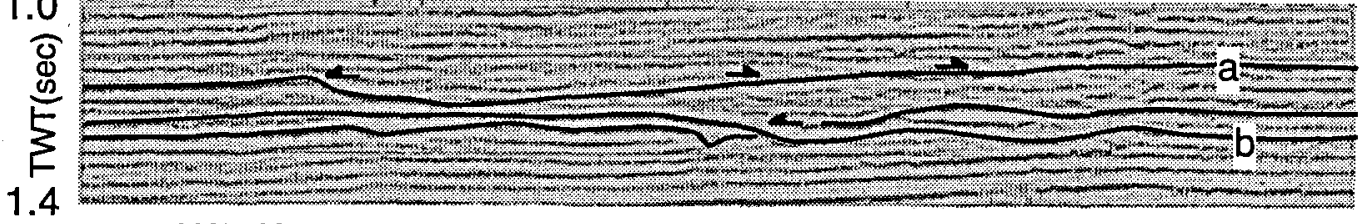

H WSW E ENE H'

\begin{tabular}{l}
$1.0 \mathrm{O}$ \\
\hline \\
\hline
\end{tabular} H

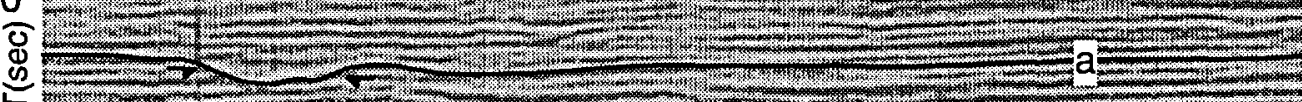

$E$

$\sum$

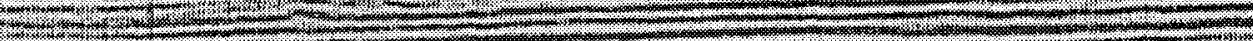

2.12.2.2.

1.4

I WSW

ENE

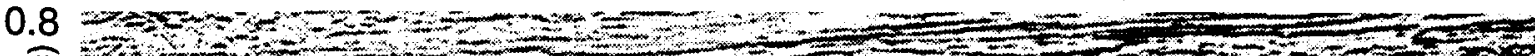

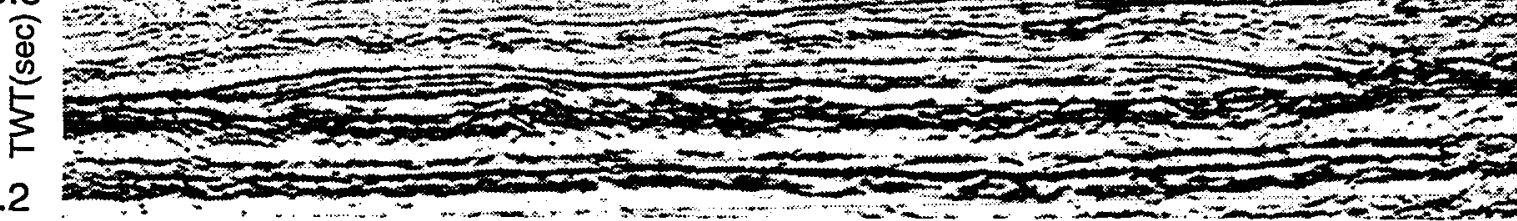

1.2

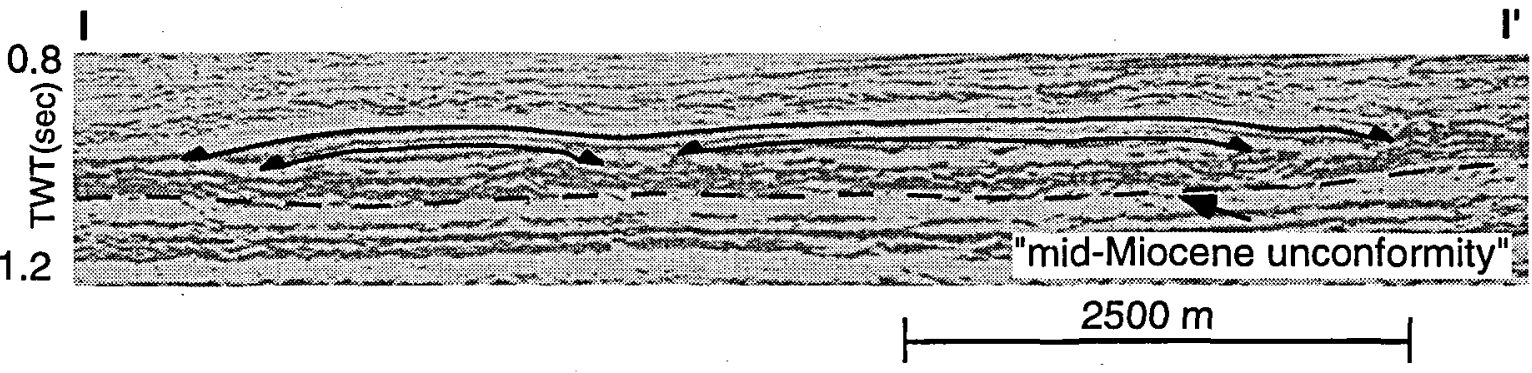

Fig. 6. On top: uninterpreted and interpreted seismic cross-sections G-G' and H-H': incised valleys oriented parallel to the axis of the Central Graben (perpendicular to the sediment transport direction) observed at the lower (b) and the upper (a) sequence boundaries of sequence 10 (Fig. 16). The features of the lower boundary (b) of sequence 10 are an example of a complex system of valleys. I-I' shows mounded structures interpreted as submarine fans (Fig. 17). For locations see Figures 1, 16 and 17). 


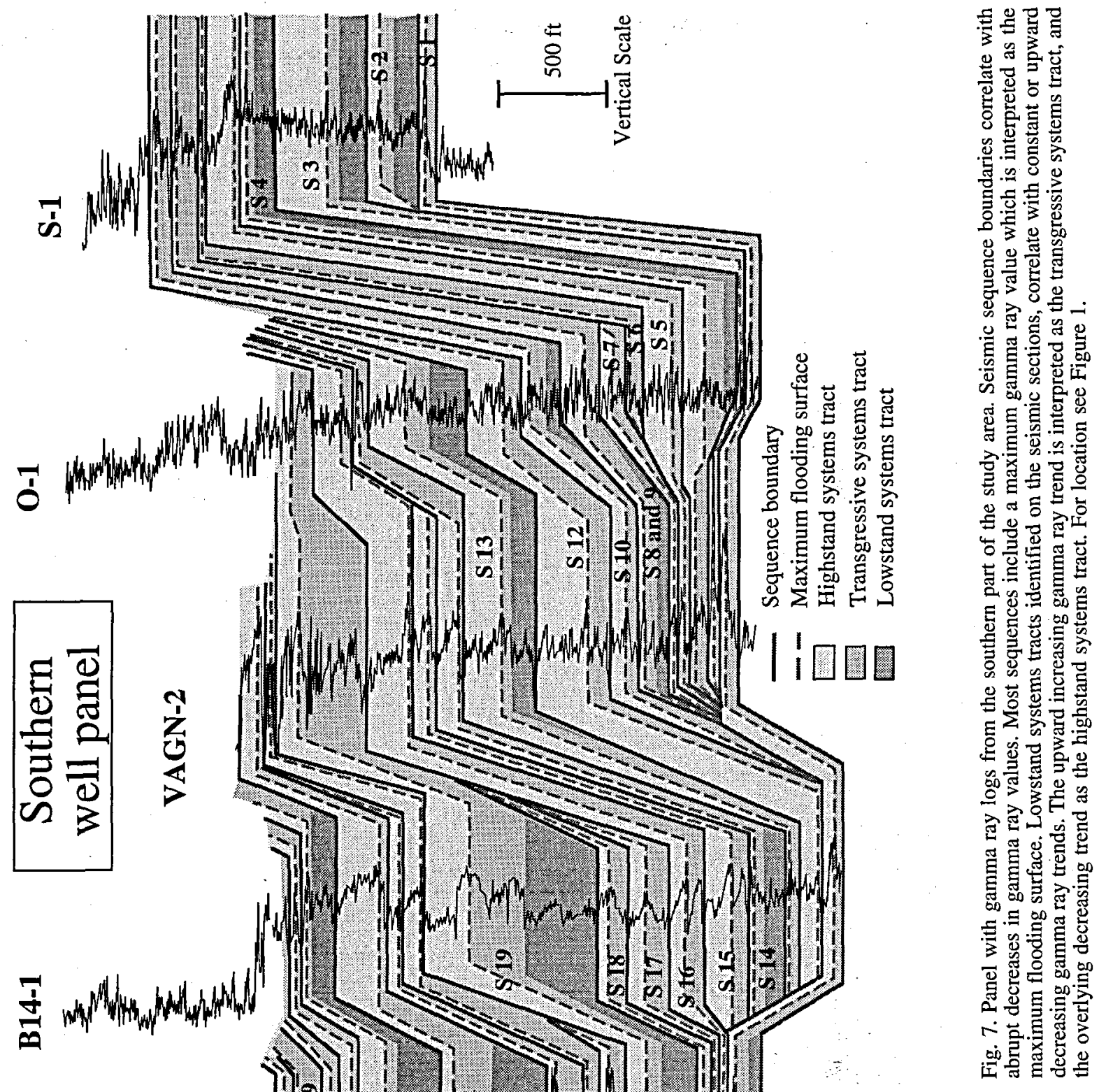

吕

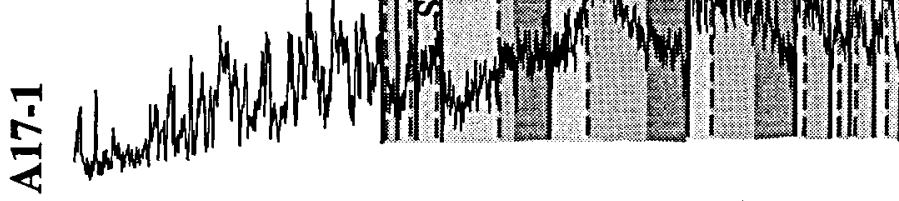




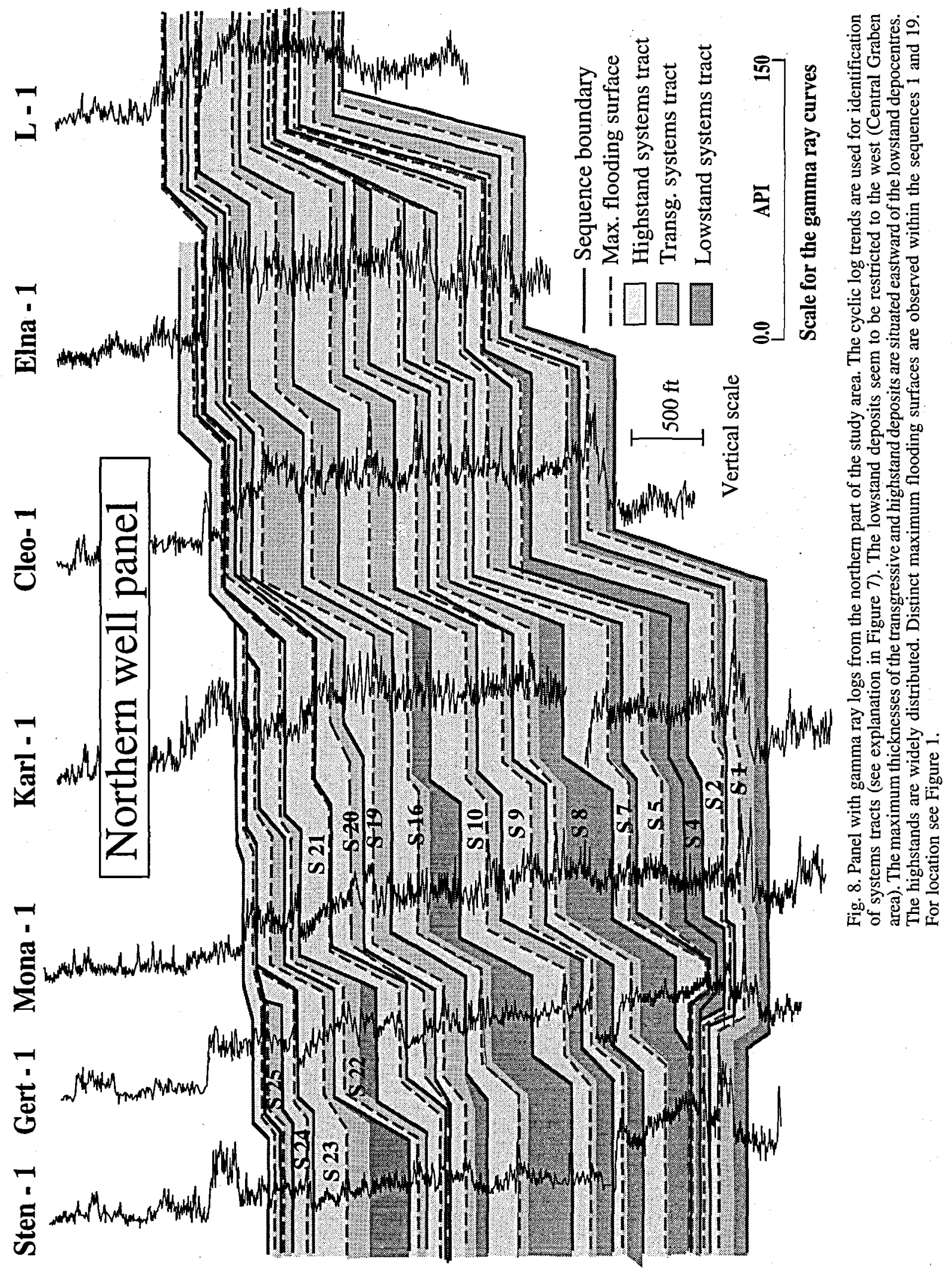




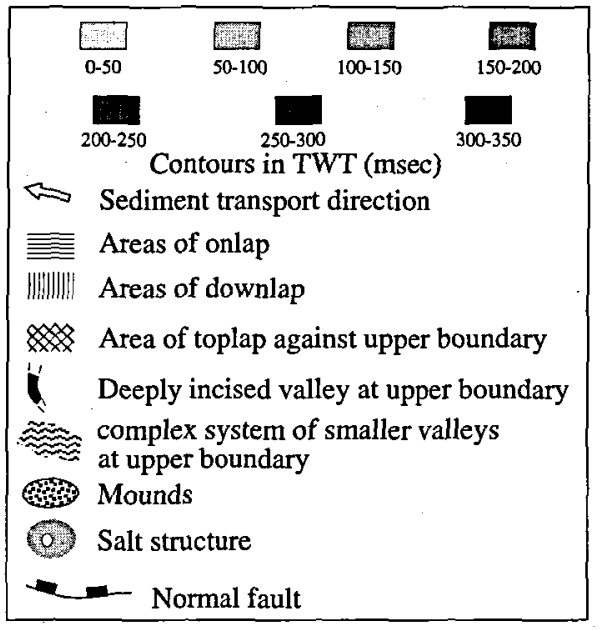

Fig. 9

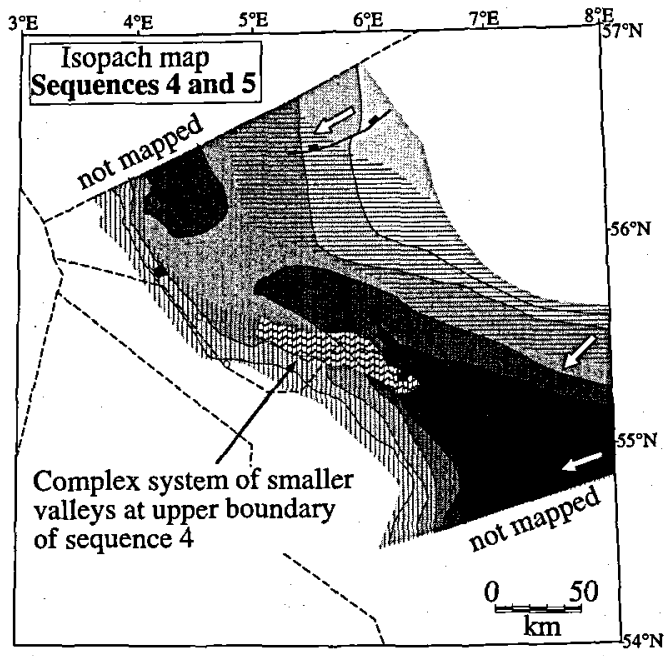

Fig. 11

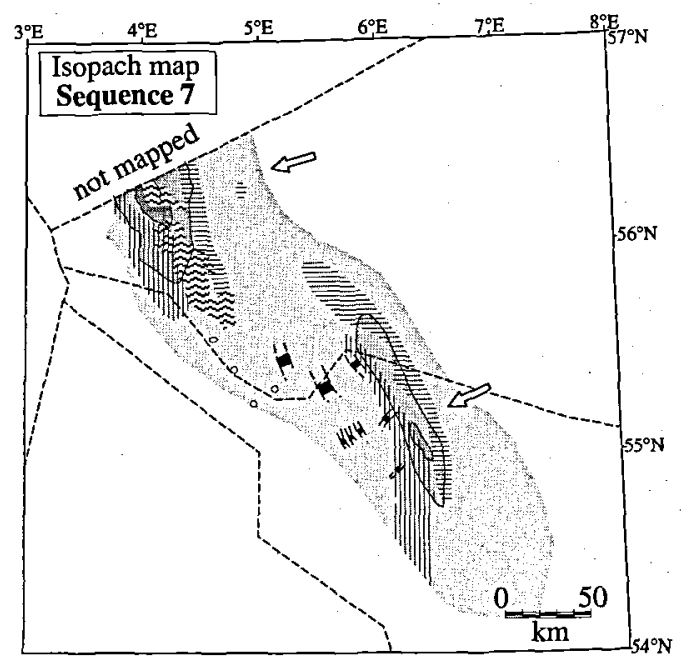

Fig. 13

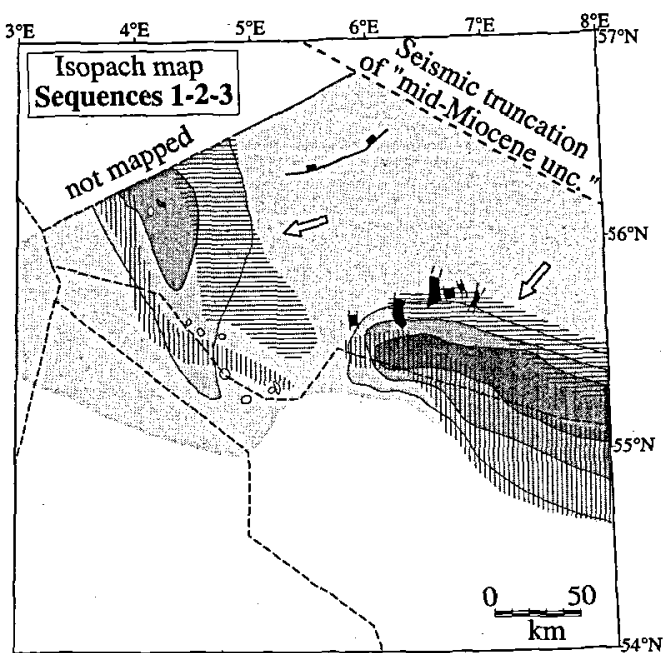

Fig. 10

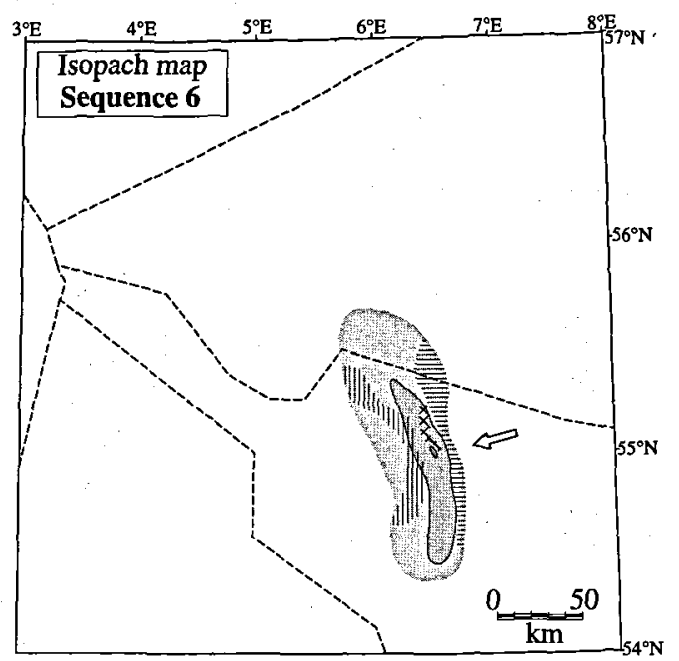

Fig. 12

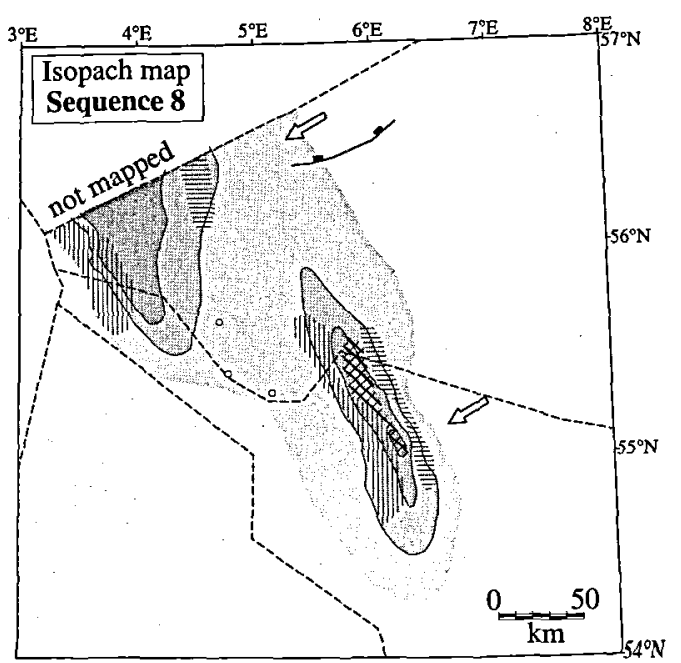

Fig. 14 


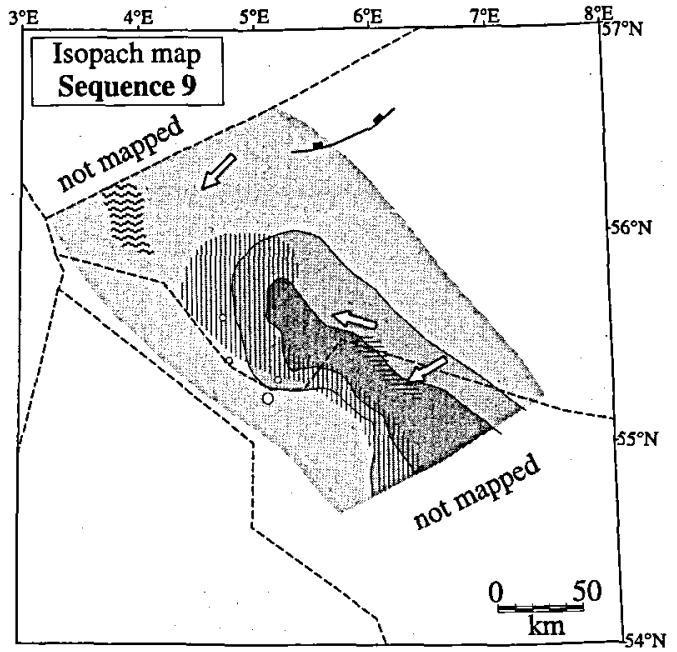

Fig. 15

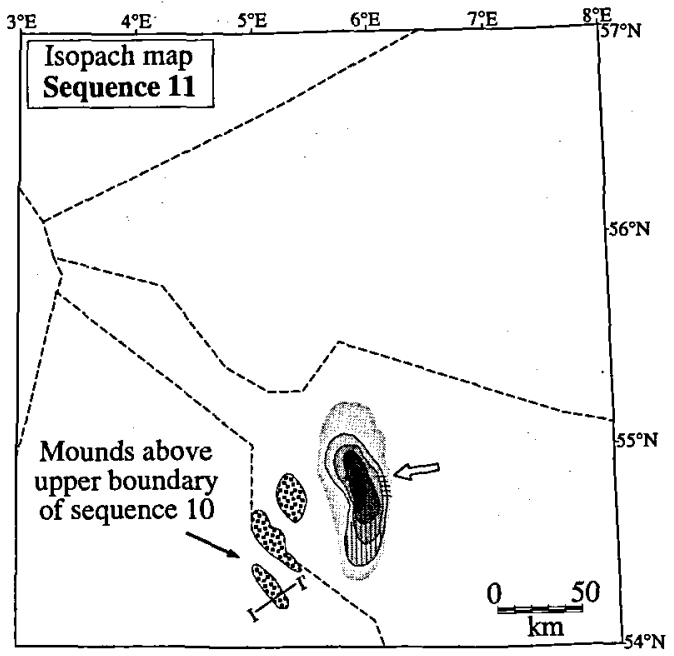

Fig. 17

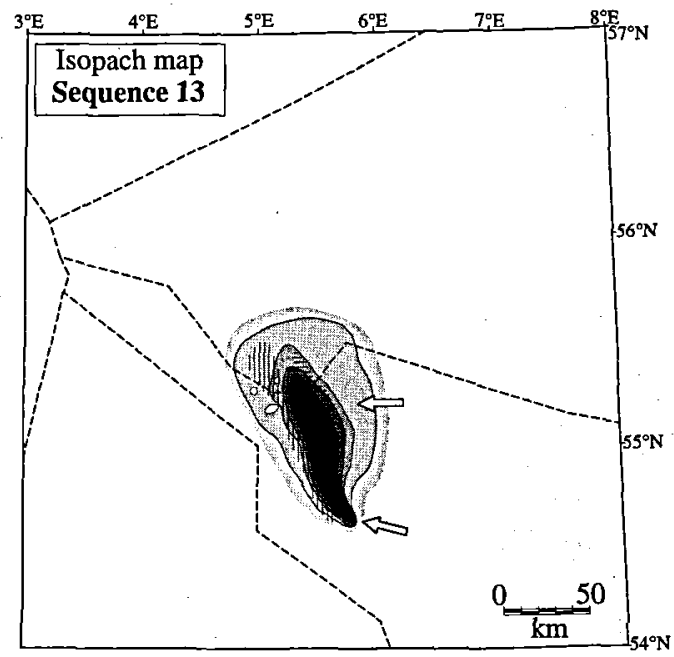

Fig. 19

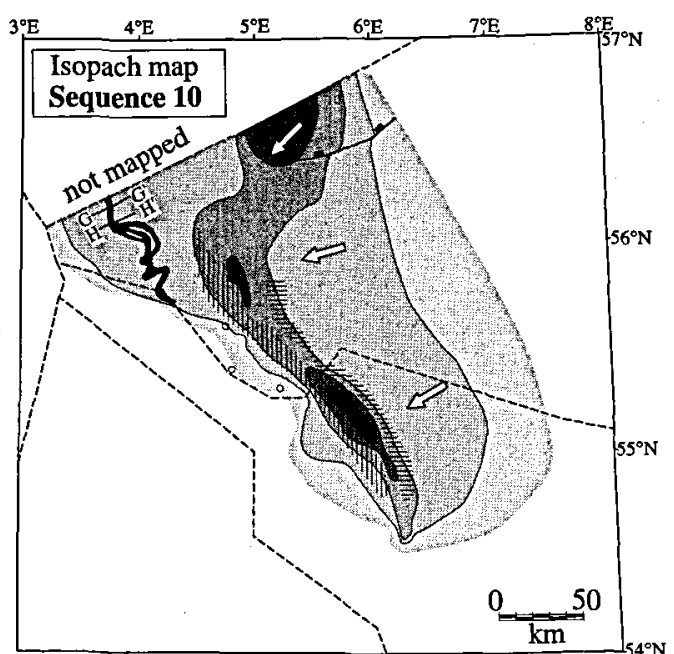

Fig. 16

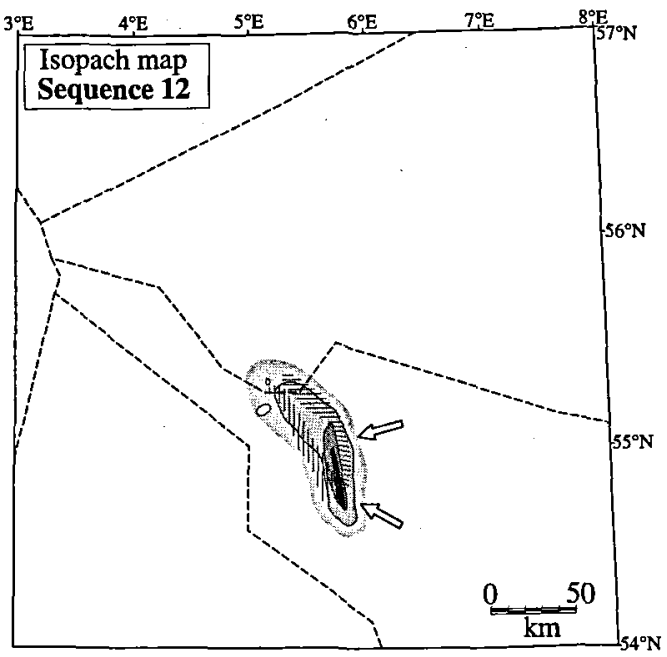

Fig. 18

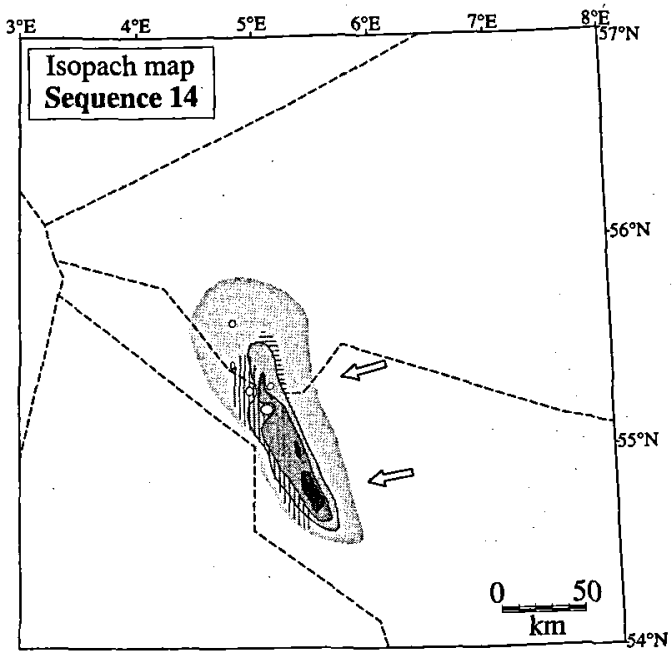

Fig. 20 


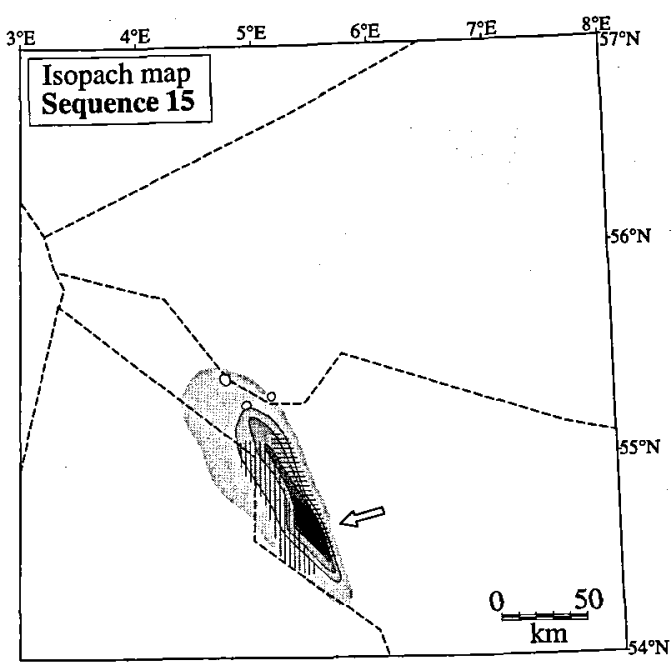

Fig. 21

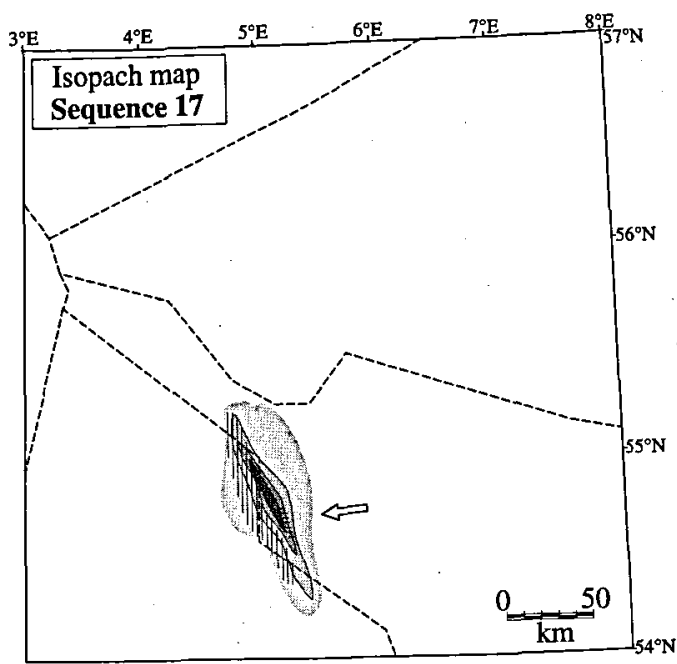

Fig. 23

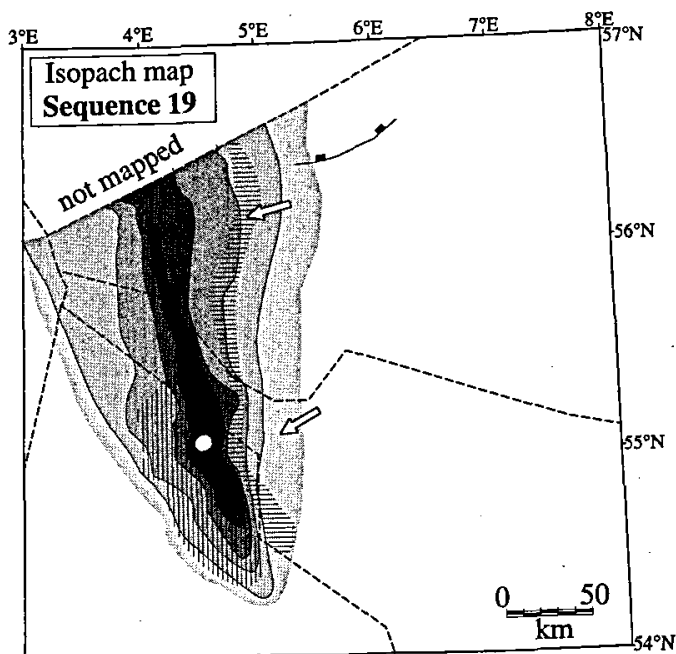

Fig. 25

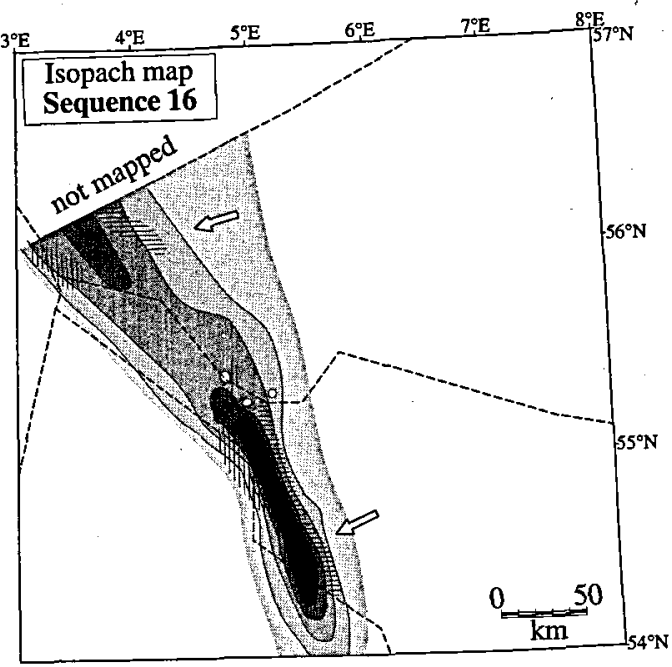

Fig. 22

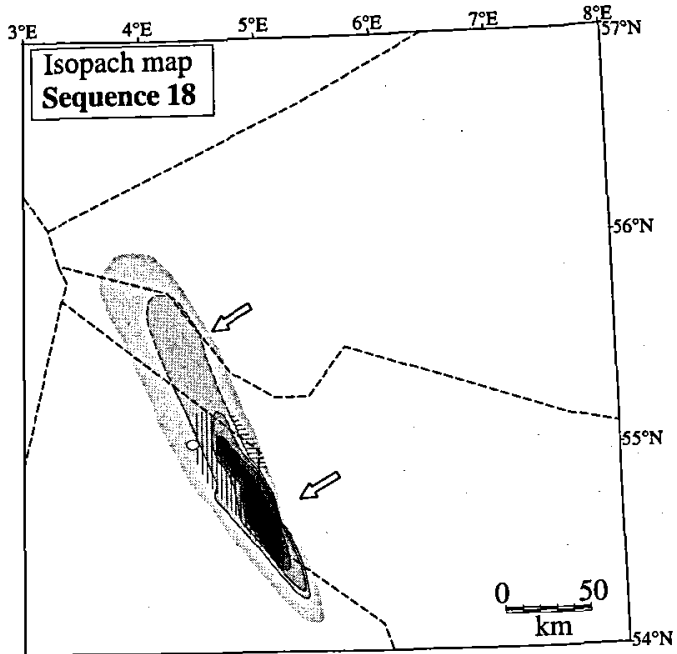

Fig. 24

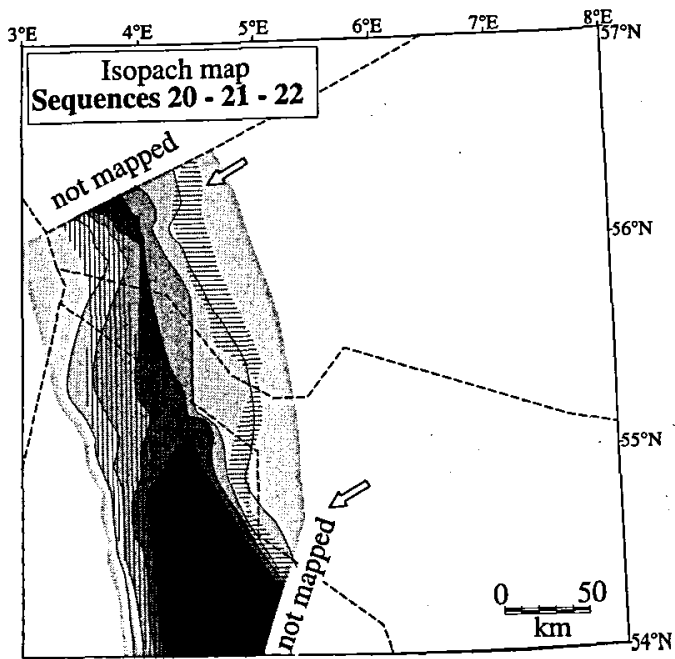

Fig. 26 


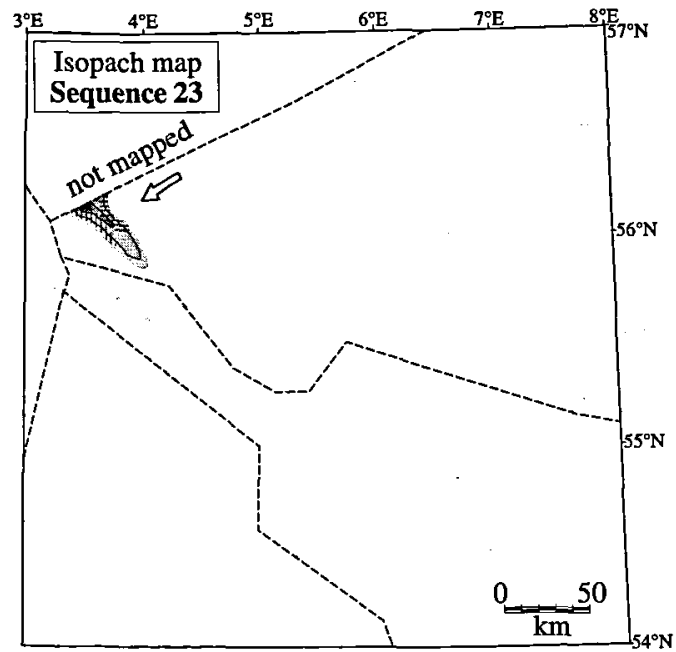

Fig. 27

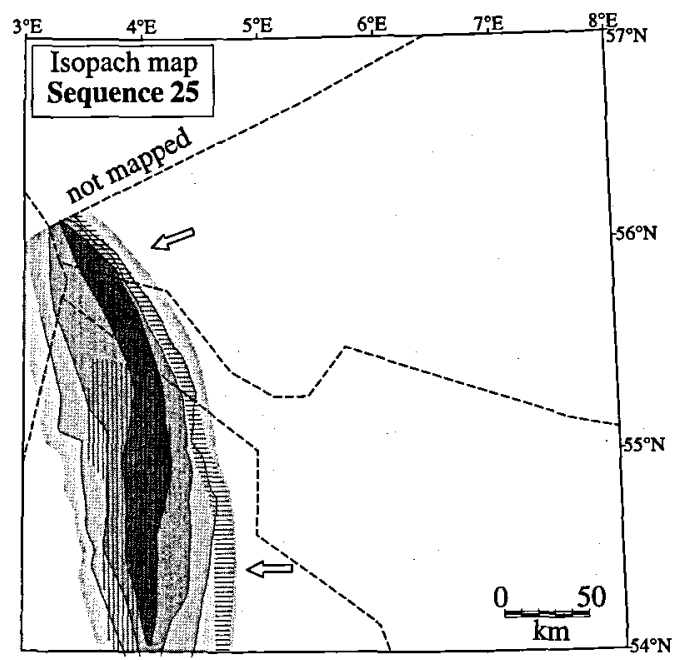

Fig. 29

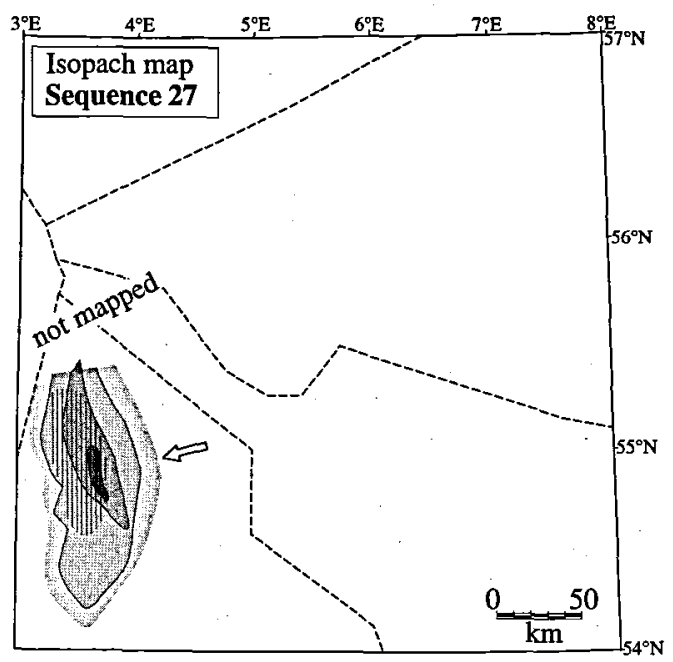

Fig. 31

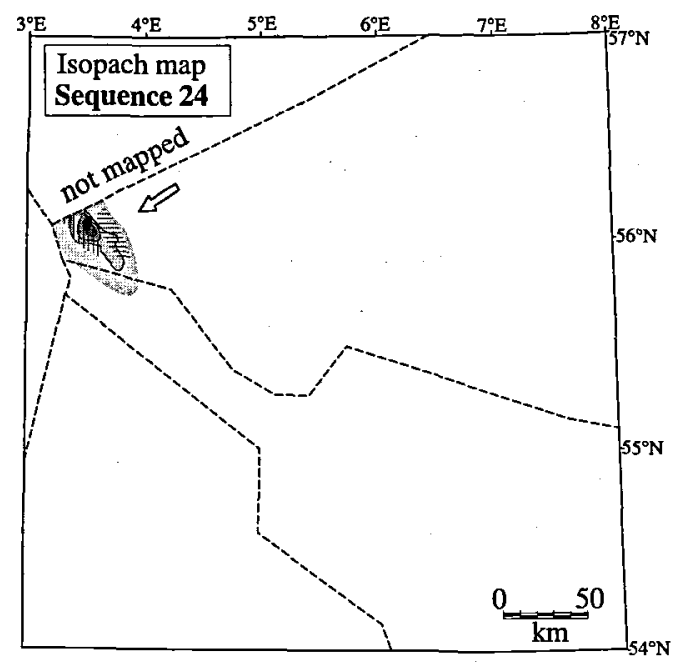

Fig. 28

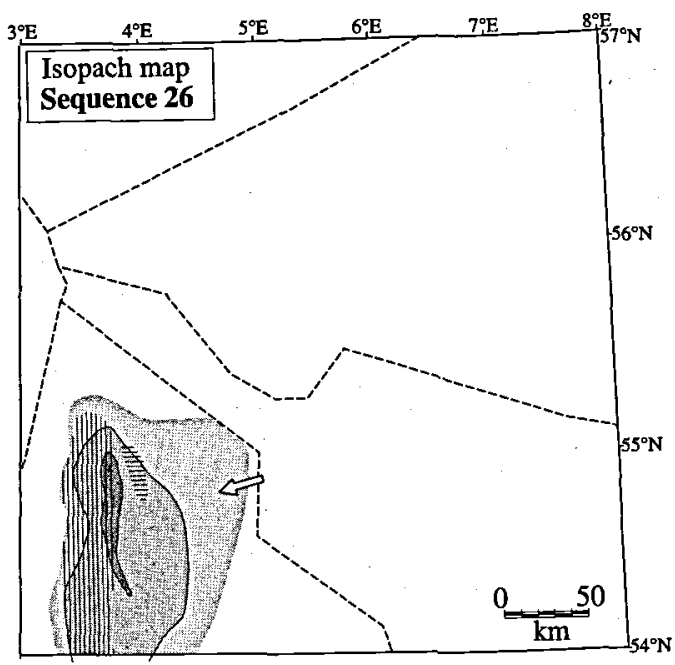

Fig. 30

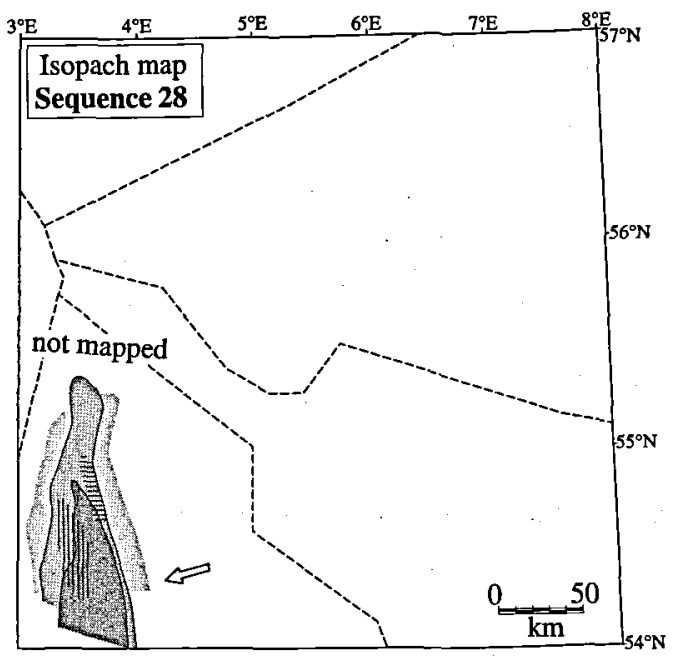

Fig. 32 
Fig. 9. Legend for the isopach maps in Figures $10-32$ and $34-35$.

Fig. 10. Isopach map of sequences 1-3. Two depocentres are observed; in the Central Graben area and along the southern flank of the Ringkøbing-Fyn High. Notice, that some of the incised valleys shown on this map are observed at the "midMiocene unconformity". The erosional features and the areas of baselap include features of the lower boundaries of the three sequences. The incised valleys are located at the southern flanks of the Ringkøbing-Fyn High and is orientated parallel to the dominating direction of sediment transport in this area.

Fig. 11. Isopach map of sequences 4 and 5 showing the main depocentre to the south in the study area and a smaller depocentre toward the north. Erosional features at the upper boundaries of sequences 4 and 5 are also shown.

Fig. 12. Isopach map of sequence 6.

Fig. 13. Isopach map of sequence 7 showing two depocentres, one toward the south of the Ringkøbing-Fyn High and another in the Central Graben area.

Fig. 14. Isopach map of sequence 8 shownng two depocentres; one south of the Ringkøbing-

Fyn High and one in the Central Graben area. Toplaps are observed at the upper sequence boundary.

Fig. 15. Isopach map of sequence 9.

Fig. 16. Isopach map of sequence 10. Erosional features at the upper boundary of sequence 10 are also shown. The deeply incised valley parallel the axis of the Central Graben.

Fig. 17. Isopach map of sequence 11. Mounded structures located at the lower boundaries of the sequences 15,18 and 19 are also shown on this map.

Figs 18-32. Isopach maps of sequences 12-28.

bably formed during the succeeding transgression. An abrupt change of gamma ray values is seen in the wells B14, A18 and A17 at the upper boundaries of the lowstand wedges in sequences 19, 25 and 26 (Fig. 7). The toplap surfaces in these sequences may be ravinement surfaces, separating lowstand deposits from the transgressive deposits (Posamentier et al., 1992). The top lowstand surface and the lower sequence boundary merge in landward direction and basinward direction (Fig. 4). The prograding lowstand wedges often correlate with intervals of upward decreasing gamma ray values or constantly low values (Fig. 7). The seismic features of the prograding lowstand deposits in sequence 10 are illustrated in Figure 33. Only a thin interval with concordant reflections represents the upper seismic unit (transgressive/highstand deposits) at this location. The prograding lowstand deposits correlate with a log interval characterized by relatively low gamma ray values and high sonic velocities in the G-1 well (Fig. 33). An isopach map of the lowstand systems tract of sequence 10 is presented in Figure 34. The lower seismic units in the northern embayment are located in the Central Graben area, whereas the depocentres of the upper seismic units, the transgressive/highstand systems tracts, are located further to the east in the Central Graben and in the NorwegianDanish Basin (Figs 8, 34 and 35).

It is difficult to locate the depositional shoreline break in the low-angled deposits. On seismic sections, the top lowstand surface is less distinct than in the highangled deposits. The gamma ray trends are here used to identify the systems tracts (Fig. 8). Lowstand systems tracts are commonly identified as intervals with low gamma ray values in the low-angled deposits.

The before-mentioned three mounded structures within sequences 15,18 and 19 are suggested to be submarine lowstand fans, because they are located at the basin floor in front of the slopes, and because the prograding lowstand wedges downlap on top of these structures (see unit 15aa in Figure 4). Thin intervals with very low gamma ray values are observed at the lower boundary of sequence 25 in the A-18 well and sequence 26 in A-17 (Fig. 7). They may represent submarine fan deposits corresponding to those of the three mounded structures.

\section{Transgressive and highstand systems tracts}

The upper seismic unit is often widely distributed in landward direction. Seismic downlaps at its lower boundary often occur in the basinward direction and onlaps in the landward direction. The upper unit is interpreted to include the transgressive and the highstand systems tracts.

The transgressive/highstand systems tract interval mostly shows low-angled seismic inclinations landwards of the depositional shoreline break of the underlying sequence. Further basinwards the inclination of the seismic retlections increases and the reflections downlap onto the lowstand wedge.

Sequences comprising high-angled strata in the southern embayment often include a thick upper seismic unit, which thins markly in the basinward direction (Figs 4 and 5). It is mostly impossible to separate the transgressive systems tract from the highstand systems tract on seismic sections (Fig. 5). On the logs, the transgressive systems tract is identified by upward increasing gamma rayvalues, and the highstand systems tract with upward decreasing intervals of gamma ray values. The log interval with maximum gamma ray values is interpreted as the maximum flooding surface (Figs 7 and 8). The gamma ray maximum correlates in some cases with a seismic downlap surface. However, the downlap surface is rarely a consistent seismic marker on a regional scale. It is rarely possible to identify the downlap surface in the lowangled deposits. In such cases, the gamma ray maxi- 


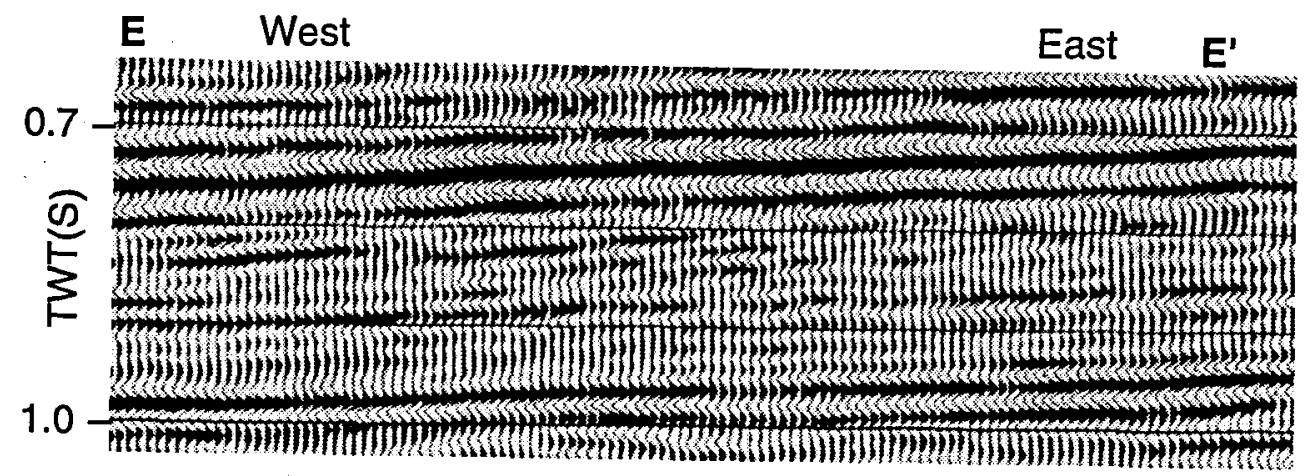

well G-1

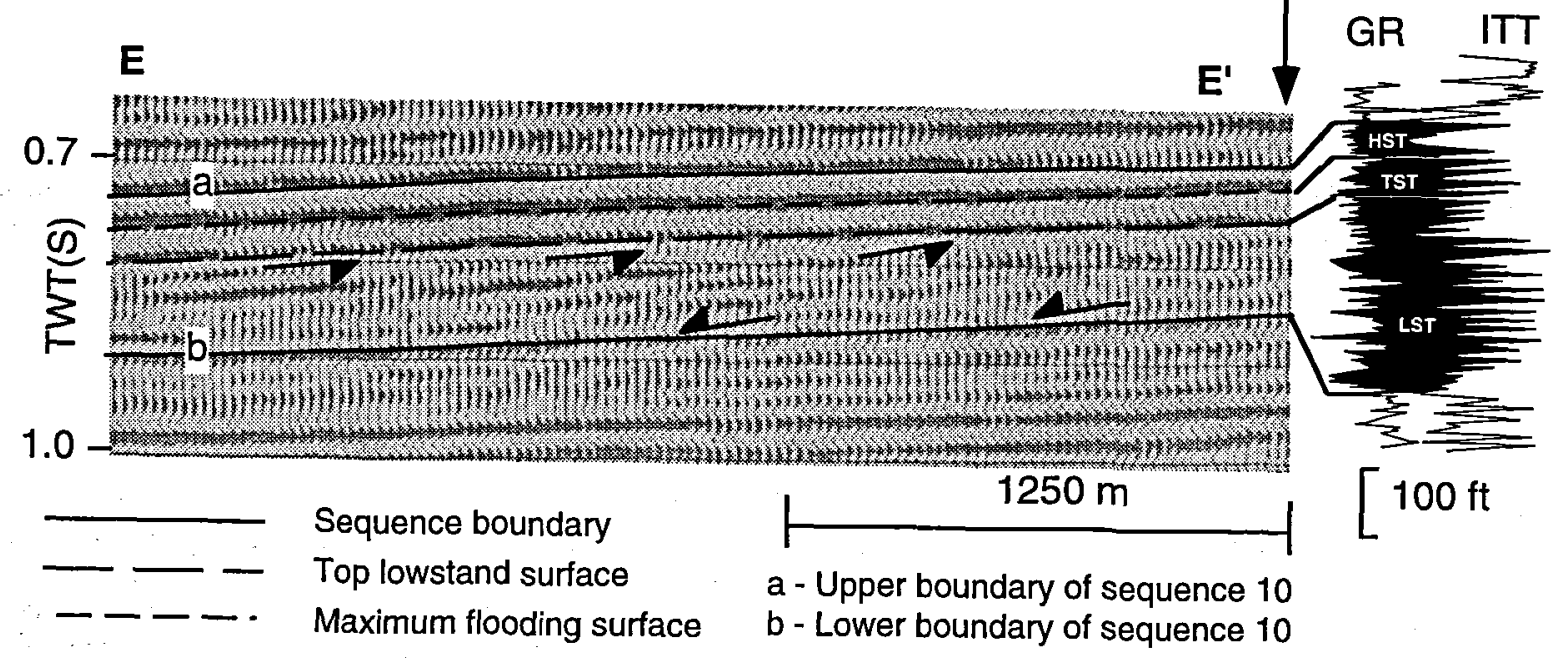

Fig. 33. A system tract interpretation of sequence 10 is demonstrated by the uninterpreted and interpreted seismic crosssection E-E' correlated with logs from the G-1 well in the southern part of the Danish sector. The lowstand systems tract is recognized as a prograding wedge on the seismic section, corresponding to an interval with slightly upward decreasing gamma ray values and variable ITT values. The transgressivel highstand systems tracts unit is recognized as a thin aggrading interval on the seismic section; the log interval shows upward increasing gamma ray values succeeded by decreasing values. For location see Figure 1.

mum correlates with a strong and continuous seismic reflection, which is used for correlations to other wells.

Sequences 10 and 19 include a relatively thick transgressive-highstand systems tract unit in the northern embayment (Figs 8 and 35). In these sequences the boundary between the transgressive and the highstand systems tract appears as a distinct seismic downlap surface. The highstand systems tract shows a highangled progradational pattern on seismic sections and the transgressive systems tract shows an aggrading reflection pattern (Fig. 36).

The very distinct gamma-ray peak within sequence 19 is observed throughout the study area (Fig. 8). This peak coincides with the downlap surface, which marks the change from a low-angled progradation to a steeper inclined progadational pattern in the northern embayment.

\section{Basin development during late Cenozoic times}

The chronostratigraphic scheme (Fig. 37) and the isopach maps (Figs 9-32) show the variation in the lateral extent of the sequences. The resolution of the available biostratigraphy, based on benthonic foraminifera zones (NSB-zones), is not sufficient to define the time interval represented by the individual sequences. The time interval between two biostratigraphic boundaries on the chronostratigraphic scheme is consequently divided into a number of equal time steps which corresponds the number of sequences within the biozone. The time interval allocated a sequence may therefore not be the true time span for deposition of the sequence. The time intervals are calculated to show graphically the chronostratigraphic positions of the sequences and to evaluate the variation of sediment accumulation rates during the late Cenozoic. The 


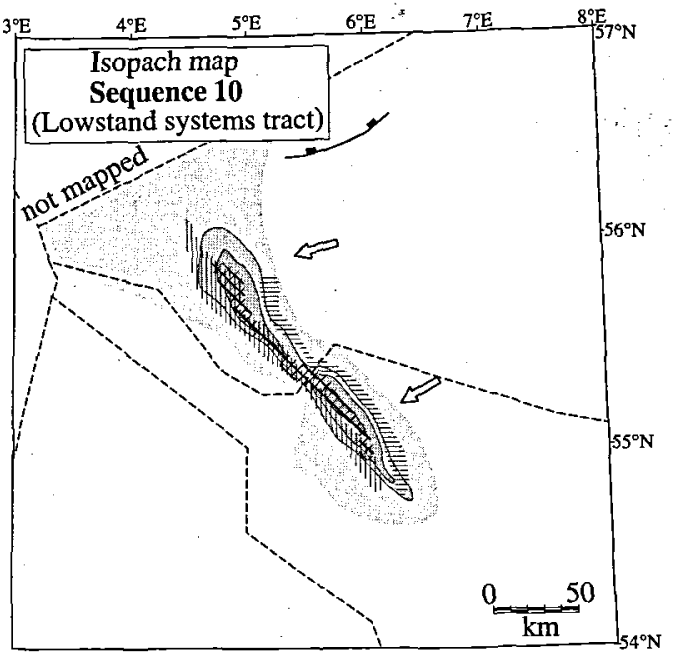

Fig. 34. Isopach map of the lowstand systems tract of sequence 10 showing an elongated depocentre toward the south in the Central Graben. A distinct toplap surface is recognized at the upper boundary. Legend, see Figure 9.

Quaternary sequences may, furthermore, be of less duration than indicated on the chronostratigraphic scheme, since the age of the youngest sequence boundary is unknown.

\section{Late Cenozoic deposition}

The study area has been separated into two depocentres by the Ringkøbing-Fyn High, a southern and a northern embayment. The isopach maps of sequences 7 and 8 show that two synchronous depositional systems were active during their deposition (Figs 13 and 14). The influence of the Ringkøbing-Fyn High have ceased at the end of Miocene times (Figs 2 and 37).

The dominant direction of sediment transport was mainly from north-northeast during deposition of sequences $1-3$, and from northeast in the remaining part of the Cenozoic. The transport directions are probably related to the late Cenozoic uplift of the Fennoscandian Shield. The uplift may furthermore have forced a regional extending river system toward the south, which would explain the change of depocentres from having a regional extent to be restricted to the southern embayment. An overall shift in deposition from the northern embayment to the southern embayment is seen in Figure 37. The deposits in the southern embayment comprise an almost continuous succession of sequences, whereas major hiati are recognized in the northern embayment. These major hiati are associated with the most distinct sequence boundaries on seismic sections in the northern embayment, e. g. the lower boundaries

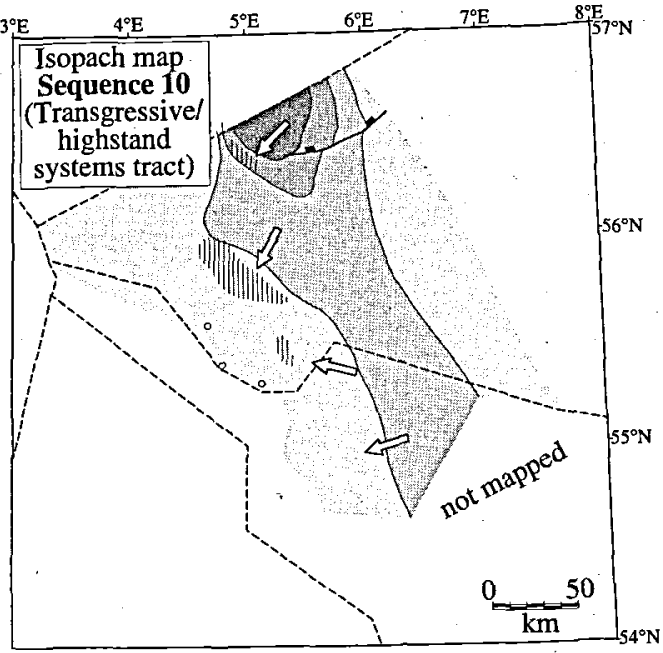

Fig. 35. Isopach map including the transgressive and highstand systems tracts of sequence 10 showing a depocentre toward the northeast of the lowstand systems tract (Fig. 34). The transgressive and highstand systems tracts are widely distributed above the Ringkøbing-Fyn High. Legend, see Figure 9.

of sequences 4 and 16 . The main subsidence and sediment accumulation during late Cenozoic times occurred to the west in the northern embayment with deposition of an approximately $1500 \mathrm{~m}$ thick succession in the northern part of the Central Graben. The Upper Cenozoic section in the southern embayment is approximately $1000 \mathrm{~m}$ thick. The stratal architecture have also different characteristics in the two embayments. High-angled progradation with seismic toplap or truncation surfaces is mainly restricted to the southern embayment. In the northern embayment lowangled progradation characterizes the lower section of the Upper Cenozoic deposits (sequences 1-16).

The height of prograding clinoforms observed on seismic sections in the southern embayment indicates considerable palaeo-water depths during deposition of sequences 10 to 18 . More than $250 \mathrm{~m}$ of palaeo-water are estimated from seismic sections at the front of some Upper Miocene prograding lowstand units, and approximately $100 \mathrm{~m}$ in front of some Quaternary prograding wedges (Figs 4 and 5).

In the northern embayment, the seismic configuration of the Pliocene and Quaternary prograding wedges in Figure 3 indicates palaeo-water depths greater than 200 metres, which is supported by the lateral distribution of foraminiferal biofacies (Konradi et al., 1995). It can, therefore, be assumed that even during periods of low sea level a deep marine seaway connected the southern embayment with the northern embayment in the central and western part of the North Sea Basin. 


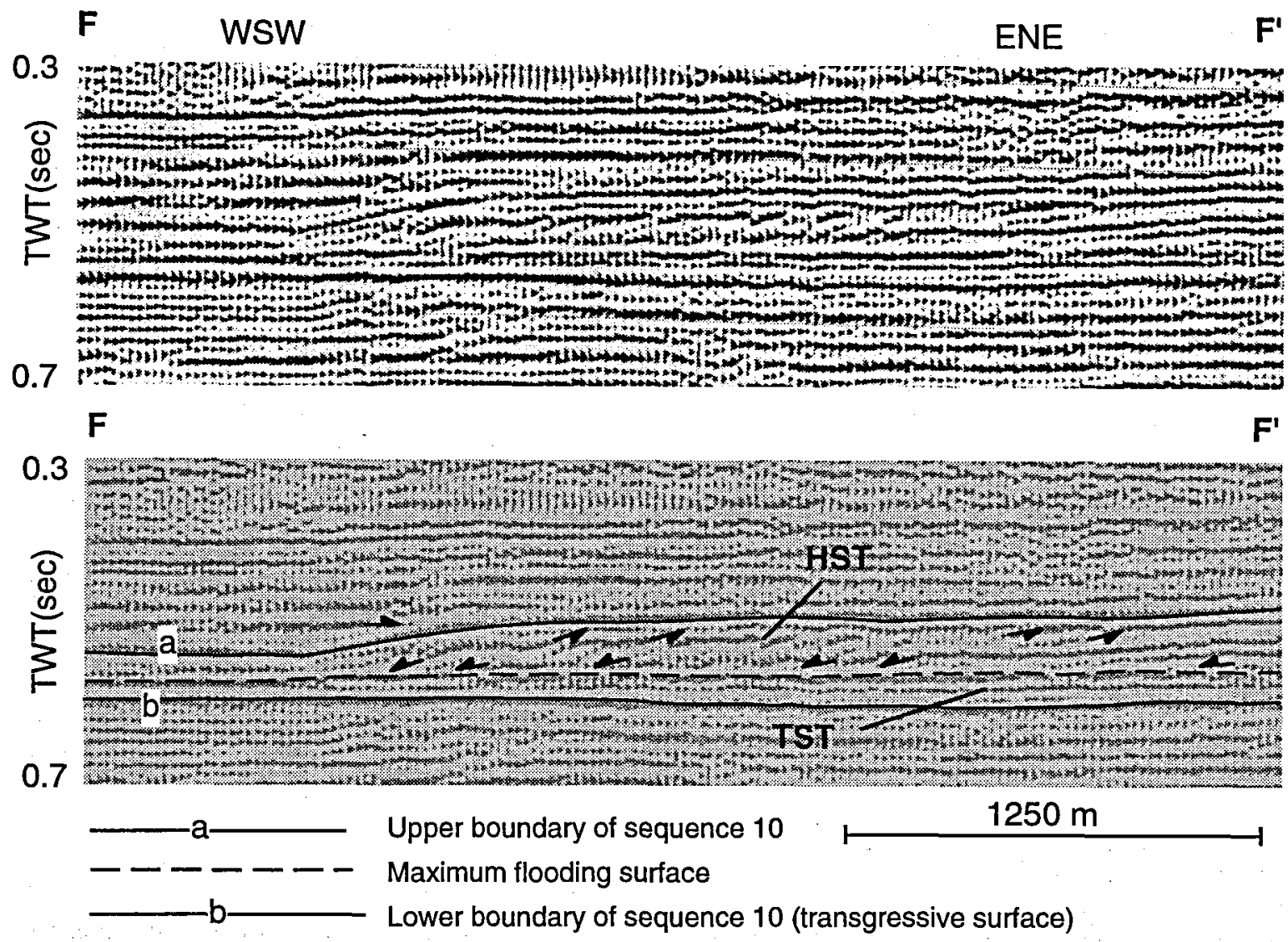

Fig. 36. Uninterpreted and interpreted seismic cross-section F-F' through sequence 10 in the northern part of the Danish sector. The lowstand systems tract is absent at this position. The highstand systems tract is recognized as a prograding wedge downlapping onto the transgressive systems tract. The small prograding wedge is located below shotpoint 6000 in Figure 3. For position see Figure 1.

\section{Relative sea level}

The two cross sections in Figure 37 reflect the relative position of sequences along the dipline of the two embayments through the times. A relative sea-level curve is constructed on the basis of the cross section from the northern embayment by drawing a curve reflecting the observed landward extent of the sequences. This curve thus represents the landward onlaps of the sequences through the time. It is assumed that this curve illustrates the major relative sea-level changes in the basin. The scale of the relative sea-level amplitudes is arbitrary, and the curve does not include small changes represented by individual sequences.

The overall trend on the sea-level curve of Haq et al. (1988) seems to correspond to those of the relative sea level curve. The distinct gamma ray peaks within sequence 1 and the distinct downlap surface within sequence 19 in the northern embayment indicate major flooding events at mid Miocene and early Pliocene times resembling the major trends of the sea-level curve of Haq et al. (1988). A relatively low sea level, indicated to have occurred in the late Miocene, also correlates to low levels on the sea-level curve of Haq et al. (1988).

Sediment accumulation rates and the palaeotemperature variations

The sediment accumulation rates through time have been calculated by computer, using digitised data from the isopach maps (Figs 9-32). A maximum sediment accumulation rate is seen in sequences with large regional extension (Fig. 37). These sequences extend further to the north of the mapped area, so if deposits in this area were included, the accumulation trend would be even more significant.

The palaeo-temperature curve of Buchardt (1978) and the sediment accumulation rates curve are compared in Figure 37. There seems to be an overall resemblance between the calculated sediment accumulation rates and the climatic oscillations, but a detailed biostratigraphic correlation of applied data is needed to demonstrate precise relationships between the two 
curves. Other factors, such as variation in basin subsidence and uplift of the Fennoscandian region, may as well have affected the sedimentation pattern. The palaeo-temperature curve shows two periods of increasing temperatures, resulting in an early to middle Miocene and an early Pliocene temperature maximum. The two temperature maxima are time-equivalent with sequence 1 and 19, both are characterized by low accumulation rates. The two major flooding events evidenced by sequences 1 and 19 seem to correlate with the two temperature maxima. The palaeo-temperatures of the sea-water in Miocene estimated by Poulsen (1995) from dinoflagellate cyst biostratigraphy in the Karl-1 well are in accordance with this correlation of palaeo-temperature maxima and major flooding events. A palaeo-temperature maximum with high winter seawater temperatures above $14^{\circ} \mathrm{C}$ is estimated within the stratigraphic interval, which corresponds to the maximum flooding surface of sequence 1 .

The decreasing palaeo-temperature shown by Buchardt (1978) during the period represented by sequences 2-10 is also recognized by Poulsen (1995). He estimated decreasing winter sea-water temperatures to below $6^{\circ} \mathrm{C}$.

The periods of decreasing palaeo-temperatures correspond to periods of increasing and high sediment accumulation rates, sequences $2-10$ and 2-25, respectively. However, these two periods are interrupted by short periods of a low sediment accumulation rate, represented by sequence 6 and sequences 23-24. During the relatively stable and cold period represented by sequences 11-18 the sediment accumulation rate was relative low.

\section{Conclusions}

The Upper Cenozoic deposits in the southeastern North Sea are subdivided into thirty-onesequences on the basis of conventional seismic sections. Systems tracts are recognized from a combined analysis of seismic sections and well logs. Lowstand systems tracts are commonly recognized as distinct prograding wedges on seismic sections. The top lowstand surface is identified as a seismic toplap surface. It is suggested to have formed as a bypass surface during lowstand progradation, but erosion is also indicated in some of the sequences and is suggested to have occurred during the subsequent transgression.

Erosional trough-shaped features occur at some sequence boundaries. Submarine erosion is suggested to have caused the erosion perpendicular to the sediment transport direction on the slope of the prograding deposits. Fluvial incision is suggested to have caused the incision parallel to the sediment transport direction and landward of the depositional shoreline break.

The Ringkøbing-Fyn High partly separated the North Sea into two embayments in Middle - Late Miocene times, a northern and a southern embayment. The embay ments were connected toward the west by a relative deep seaway. The palaeo-water depths estimated from the heights of the prograding clinoforms exceeded $200 \mathrm{~m}$ in certain periods. An overall high-angled prograding stratal pattern dominates the deposits in the southern embayment, whereas a low-angled stratal pattern dominates the late Miocene deposits in the northern embayment. However, in Pliocene and Quaternary times the deposits in the northern embayment show high-angled progradation. The southern embayment comprise an almost continuous series of sequences, whereas major hiati are identified in the northern embayment.

The overall trends of the relative sea-level curves and the sediment accumulation rates correlate with published curves for eustatic sea-level changes and palaeo-temperatures, respectively. During periods of decreasing palaeo-temperatures, the sediment accumulation increased and during periods of increasing palaeo-temperatures, the sediment accumulation decreased. Two palaeo-temperature maxima seem to correspond to the most distinct maximum flooding surfaces observed in the Mid Miocene and Lower Pliocene deposits. Periods of stable palaeo-teemperature correspond to relative low sediment accumulation rates.

\section{Acknowledgement}

During a part of the research period, Jan Sørensen received financial support from the Danish Energy Agency. We also wish to acknowledge the fruitful discussions we had with our colleagues in the Department of Earth Sciences, Aarhus University, especially to Ulrik Gregersen who commented early versions of the manuscript and Bo Frank $\varnothing$ who has reprocessed the seismic section RTD81-22. Special thanks are given to Finn Surlyk and Svend Stouge who reviewed and commented the manuscript.

\section{Dansk sammendrag}

De Øvre Miocene aflejringer over den ,midt Miocæne inkonformitet" $i$ det sydøstlige Nordsø Bassin er i nærværende arbejde blevet inddelt $\mathrm{i}$ enogtredive sekvenser. En overvejende progradering fra øst mod vest er observeret. Sekvenserne er inddelt i systemområder ved en integreret analyse af seismiske sektioner og petrofysiske borehulslogs. Lavstandssystemerne fremstår seismisk som prograderende legemer. Den $\emptyset$ vre grænse for lavstandssystemet fremtræder som en markant toplapflade i områder, hvor kraftig progradering dominerer lagmønsteret. Erosion i toplap-fladen er dog indikeret i nogle sekvenser, og antages at have fundet sted under den efterfølgende transgression. Den maksimale overskyldsflade er identificeret som et snæveret log- 


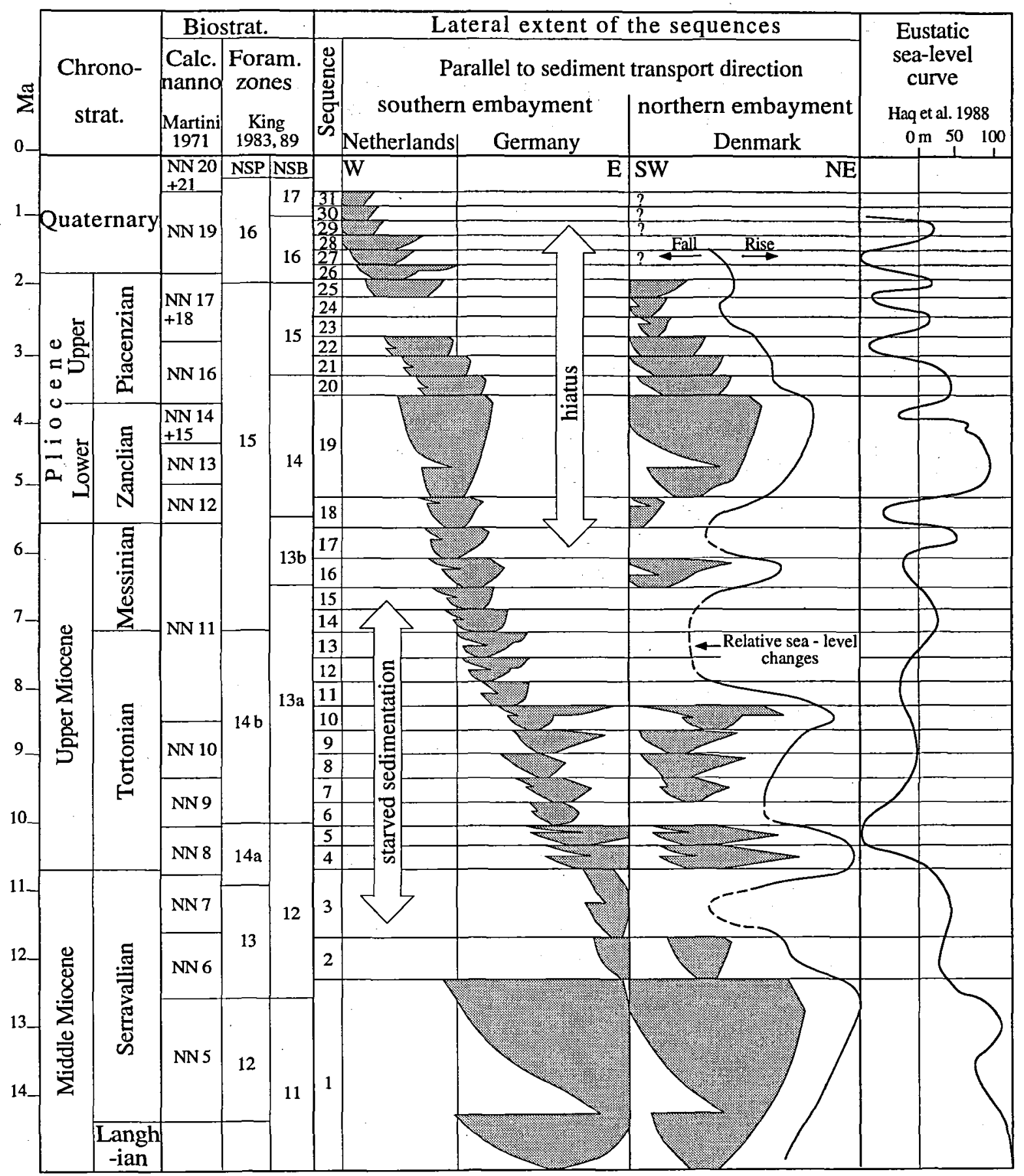

Fig. 37. Scheme showing the chronostratigraphic age of the sequences. The lateral extent of the sequences is demonstrated by two cross-sections parallel with the dominant direction of sediment transport in the southern embayment and the northern embayment, respectively, and by one cross-section perpendicular to the transport direction. Observed downlap surfaces are indicated by an increasing interval of starved sedimentation in basinward direction. An overall relative sealevel curve is suggested on the basis of the varying position of sequences in the basin. The scale of the sealevel amplitudes is arbitrary. The sediment accumulation rate through time is shown to the right in the figure. The palaeo-temperature curve is modified from Buchardt (1978). 


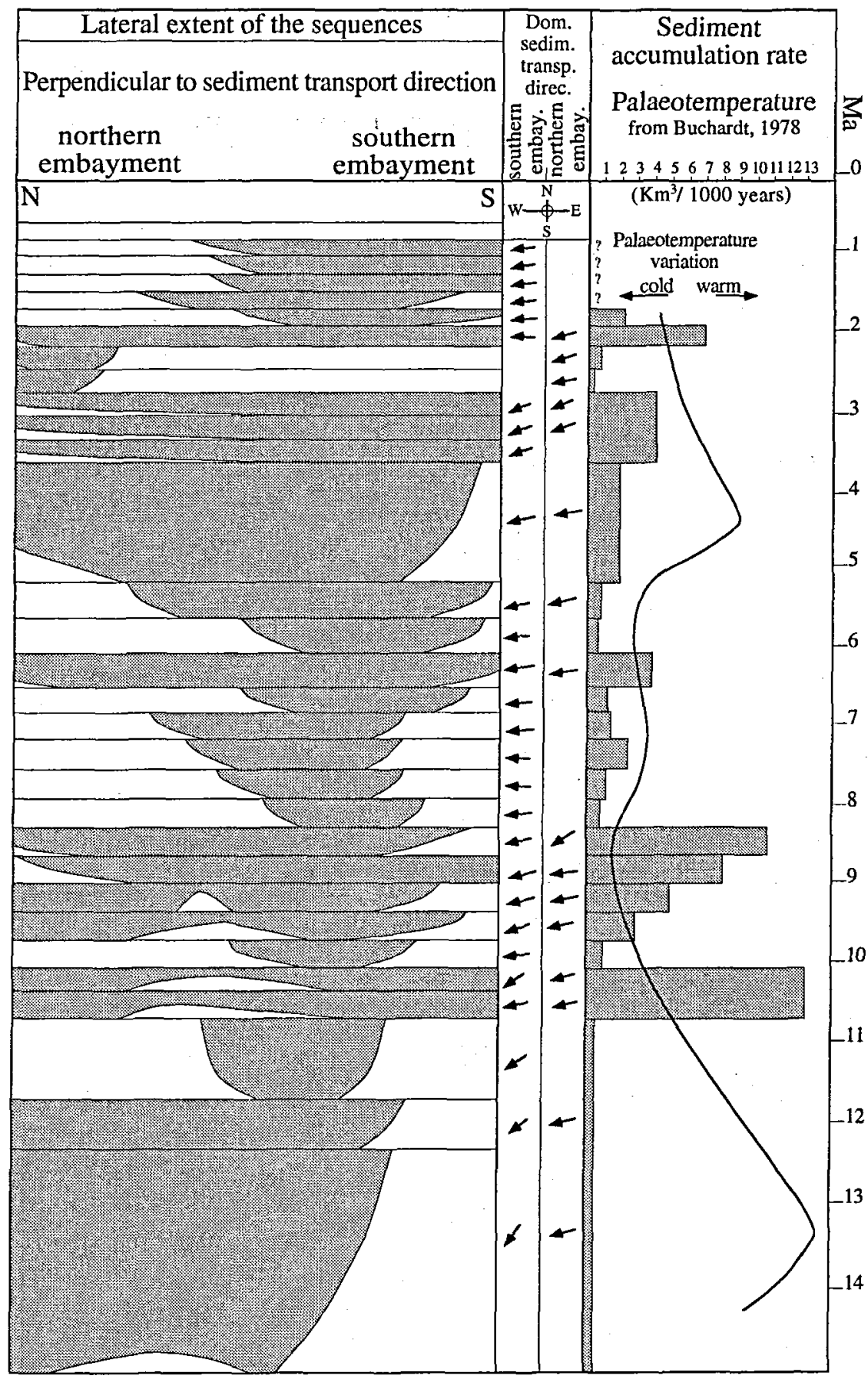


interval med høje gamma-ray værdier. Det transgressive system og højstandssystemet kan derfor identificeres som henholdsvis opad finende og opad grovende log-trends, medens de to systemer som oftest ikke kan adskilles på de seismiske data.

Vidt udbredt erosion er observeret i forbindelse med nogle sekvensgrænser, henholdsvis parallelt med og vinkelret på hældningsretningen af de prograderende aflejringer. Erosionsdale vinkelret på hældningsretningen forekommer topografisk under prograderingsfrontens top og antages dannet under havoverfladen. Erosionsdale parallelt med hældningsretningen forekommer landværts for prograderings-frontens top og antages dannet ved fluviatil aktivitet.

I Sen Miocæn udgjorde Ringkøbing-Fyn Højderyggen en submarin barriere i de østlige dele af bassinet, og opdelte herved Nords $\varnothing$ Bassinet $i$ et nordligt og et sydligt aflejringsomrtde. De to områder var forbundet med en relativ dyb havforbindelse mod vest. Palæovanddybden i denne oversteg til tider $200 \mathrm{~m}$. En næsten komplet følge af sekvenser er repræsenteret i det sydlige område, hvorimod større hiati er konstateret $i$ det nordlige område.

Aflejringshastighederne synes at have kulmineret $\mathrm{i}$ perioder med aftagende eller lave palæo-temperaturer. Under relativt stabile og kolde perioder aflejredes sekvenserne som prograderende legemer med en begrænset lateral udbredelse. I perioder med tiltagende eller høj palaeo-temperatur aftog aflejringshastigheden. To perioder med maksimale palæo-temperaturer synes at være samtidige med to markante overskyldsflader.

\section{References}

Bijlsma, S. 1981: Fluvial sedimentation from the Fennoscandian area into the north-west European Basin during the Late Cenozoic. Geologie en Mijnbouw 60, 337-345.

Buchardt, B. 1978: Oxygen isotope palaeo-temperatures from the tertiary period in the North Sea area. Nature 275. 121-123.

Cameron, T. D. J., Bulat. J. \& Mesdàg, C. S. 1993: High resolution seismic profile through a late Cenozoic delta complex in southern North sea. Marine and Petroleum Geology 10, 591-599.

Clausen, O. R. \& Korstgård, J. A. 1993: Small-scale faulting as an indicator of deformation mechanism in the Tertiary sediments of the northern Danish Central Trough. Journal of Structural Geology 15, 1343-1357.

Deegan, C. E. \& Scull, B. J. 1977: A standard lithostratraphic nomenclature for the central and northern North Sea. Institute for Geological Sciences Report 77/25, NPD - Bulletin $1, .35 \mathrm{pp}$.

Eisma, D. \& Kalf, J. 1987: Dispersal, concentration and deposition of suspended matter in the North Sea. Journal of the Geological Society London 144, 161-178.

Haq, B. U., Hardenbol, J. \& Vail, P. R. 1988: Mesozoic and Cenozoic chronostratigraphy and cycles of sea-level change. In: Wilgus, C. K., Posamentier, H., Roos, C.A. \&
Kendall. C. (eds.) Sea-Level Changes - An Integrated Approach. Society of Economic Paleontologists and Mineralogists Special Publication 42, 71-108.

Helland-Hansen, W. \& Gjelberg, J. G. 1994: Conceptional basis and variability in sequence stratigraphy: a different perspective. Sedimentary Geology 92, 31-52.

Japsen, P. 1993: Influence of lithology and Neogene Uplift on Seismic velocities in Denmark: Implications for Depth Convertion Maps. American Association of Petroleum Geologists Bulletin 77, 194 -211.

Jensen, L. N. \& Schmidt, B. J. 1992: Late Tertiary uplift and erosion in the Skagerrak area: Magnitude and consequences. Norsk Geologisk Tidsskrift 72, 275-279.

Jensen. L. N. \& Michelsen, O. 1991: Tertiær hævning og erosion i Skagerrak, Nordjylland og Kattegat. Dansk Geologisk Forenings Årsskrift 1990-91. 159-168

Kay, C. J. 1993 The growth and glÀoss morphology of Quaternary deltas In the southernNorth Sea. Unpublished $\mathrm{Ph}$. D Thesis University of Edinburgh.

Kockel, E 1988: Base "Middle Miocene" structural contour map. In Vinken, R. (ed.) The Northwest European Tertiary Basin. Geologisches Jahrbuch A 100, 423-428.

Konradi, P, Lauersen, G. \& Bidstrup, T. 1995: Seismic sequence stratigraphy and foraminiferal biofacies in a profile into the Central Trough, North Sea. Unpublished report for the Danish Energy Agency.

Kristoffersen, E N. \& Bang, I. 1982: Cenozoic excl. Danian limestone. In Michelsen, O. (ed.) Geology of the Danish Central Graben. Danmarks Geologiske Undersøgelse B 8, 61-70.

Michelscn, O. \& Nielsen, L. H. 1993: Structural development of the Fennoscandian Border Zone. offshore Denmark. Marine and Petroleum Geology 10, 124-134.

Michelsen. O., Thomsen, E., Danielsen, M., Heilmann-Clausen, C., Jordt, H. \& Lauersen. G. V. (in press): Cenozoic sequence stratigraphy in eastern North sea. In de Graciansky, P. C., Jacquin, T. \& Vail, P. R. (eds.): Mesozoic-Cenozoic sequence stratigraphy of western European basins. Society of Economic Paleontologists and Mineralogists.

Posamentier, H. W., Alien, G. P, James, D. P \& Tesson. M. 1992: Forced regressions in a sequence stratigraphic framework: Concepts, examples, and exploration significance. American Association of Petroleum Geologists Bulletin 76, 1687-1701.

Posamentier, H. W., Vail, P. R. 1988. Eustatic controls of elastic deposition II. In: Wilgus, C. K., Posamentier, H., Roos, C. A. \& Kendall, C. (eds.): Sea-Level Changes An Integrated Approach. Society of Economic Paleontologjsts and Mineralogists Special Publication 42, 125-154.

Poulsen, N. E. 1995: Neogene and Quaternary dinoflagellate cyst biostratigraphy and paleoclimatology of the Karl-1 borehole, Central Trough in the Danish North Sea area. Unpublished report for the Danish Energy Agency.

Rundberg. Y. 1989: Tertiary sedimentary History and Basin evolution of Norwegian North Sea between 60 degree N An Integrated Approach. Unpublished Dr. ing. Thesis, Tronheim Universitetet, Norge, $292 \mathrm{pp}$.

Sørensen, J. C. 1993: En sekvensstratigrafisk inddeling af neogene og kvartære aflejringer i Central Truget. Unpublished M. Sc. thesis. University of Aarhus, $101 \mathrm{pp}$.

Vail, P.R. 1987: Seismic stratigraphy interpretation using sequence stratigraphy, part 1: Seismic stratigraphy interpretation procedure. In Bally, A. W (ed.) Atlas of seismic stratigraphy. American Association of Petroleum Geologists Studies in Geology 27. 1, 1-10. 
Vail, P R. \& Wornardt Jr., W 1991: An integrated approach to exploration and development in the $90 \mathrm{~s}$ : Well log-seismic sequence stratigraphy analysis. Transactions-Gulf Coast Association of Geological' Societies, XLI. 1991, 329-349.

Van Wagoner, J. C., Mitchum. R. M., Posamentier. H. W. \& Vail, P. R. 1987: Seismic stratigraphy interpretation using sequence stratigraphy, Part 2: Key definitions of sequence stratigraphy. In Bally. A. W. (ed.) Atlas of seismic stratigraphy. American Association of Petroleum Geologists Studies in geology 27. 1, 11-14.

Van Wagoner, J. C., Mitchum, R. M., Campion, K. M. \& Rahmanian, V. D. 1990: Siliciclastic Sequence Stratigraphy in Well Logs, Cores, and Outcrops: Concepts for HighResolution Correlation af Time and Fades. American Association of Petroleum Geologists Methods in Exploration Series 7, $55 \mathrm{pp}$.

Ziegler. P A. 1982: Geological Atlas of Western and Central Europe. 130 pp. Amsterdam: Elsevier.

Ziegler, P A. 1988: Evolution of the Arctic-North Atlantic and the Western Tethys. American Association of Petroleum Geologists Memoir 43, 198 pp. 